\title{
The Trajectory of (Corporate Law) Scholarship ${ }^{*}$
}

\author{
Brian R. Cheffins
}

S.J. Berwin Professor of Corporate Law, Faculty of Law, University of Cambridge

August 2003

* The author is grateful for comments by Deborah DeMott and Lynn Stout and for feedback received at law faculty seminars at U.C.L.A. and the University of Manchester. 


\title{
The Trajectory of (Corporate Law) Scholarship
}

\author{
Brian R. Cheffins
}

\author{
S.J. Berwin Professor of Corporate Law \\ Faculty of Law, University of Cambridge \\ e-mail: brc21@cam.ac.uk
}

\begin{abstract}
While considerable attention is devoted to legal scholarship, little has been written on the process by which academic writing on law evolves. This paper departs from the existing pattern and examines five potential trajectories for legal scholarship. One is based on the idea that knowledge "accumulates" as part of "progress" towards a better understanding of the matters under study. The second is the concept of the "paradigm", derived from work done on the history and sociology of science. The third focuses on the idea that academic endeavor concerning law yields useful ideas since market forces are at work. The fourth is a "cyclical" thesis, based on the assumption that themes legal scholars write about arise on a reoccurring basis. Finally, legal scholarship can potentially be characterized in terms of fads and fashions.

It appears that scholarly trends in law develop in a manner that is at least partially consistent with each of the five potential trajectories identified. At the same time, none captures fully the dynamics at work and indeed there is some conflict between the various paths available. The paper tests these conjectures by focusing on a particular topic, namely corporate law. The survey offered does not identify one of the five potential trajectories as being dominant. Still, each does help to explain how corporate law scholarship has developed. Correspondingly, for those who are interested in why some ideas prosper whereas other claims "burn out", this paper offers a "test-driven" analytical framework that can be applied to discern how academic writing on law evolves over time.
\end{abstract}




\section{INTRODUCTION}

Legal academics, despite facing inevitable teaching and administrative pressures, spend a considerable portion of their career reading, discussing and producing legal scholarship. ${ }^{1}$ In so doing, most will develop a sense of why certain ideas spread and prosper whereas as other claims "burn out" or fail to capture attention in the first place. Still, while academic lawyers may make assumptions about the trajectory of legal scholarship, their understanding of the topic will almost certainly be intuitive only. This is because, despite the attention devoted to scholarly activity, there is little literature on the process by which academic writing on law evolves. In other words, there is "no jurisprudence of legal scholarship". 2

A 2001 article by law professor Cass Sunstein illustrates the lack of attention devoted to the trajectory of academic literature on law. He argues in this paper that in law ideas spread via academic "fads" rather than by virtue of being "good". In so doing, he discusses only briefly why legal scholarship might evolve differently than in the manner he suggests. ${ }^{3}$ In so doing, perhaps he was assuming that alternative theories were so well-known that articulation would be superfluous. In fact, however,

1 John Gava, Scholarship and Community, 16 SYDNEY L. REV. 443, 443 (1994).

2 George P. Fletcher, Two Modes of Legal Thought, 90 YALE L.J. 970,970

(1981). The situation has not changed recently: Deborah L. Rhode, Legal Scholarship, 115 HARV. L. REV. 1327, 1327 (2002).

3 Cass R. Sunstein, Foreword: On Academic Fads and Fashions, 99 MiCH. L. REV. 1251, 1253-54 (2001). He only included his discussion of the topic at the suggestion of several commentators on an earlier draft (at 1253, n. 5). Sunstein in fact was critiquing the notion that there is a "market" for legal scholarship, discussed infra notes $\mathrm{xx}$ to $\mathrm{xx}$ and accompanying text. 
a search for a fully developed analysis of the trajectory of legal scholarship will probably be in vain. ${ }^{4}$

This paper departs from the existing pattern and examines various possible ways in which academic work concerning law evolves. Such an exercise might be thought by some to constitute introverted navel-gazing. The volume of legal scholarship is, however, mushrooming and there indeed is a growing literature on the genre. $^{5}$ Given all of this intellectual endeavor, it is appropriate to pause and seek to discern the trajectory of legal scholarship.

No one is truly competent to evaluate properly the overall state of legal scholarship. ${ }^{6}$ Correspondingly, this paper will not seek to determine in a definitive way the manner in which academic writing on law evolves. Instead, it is more of a thought experiment, with the central objective being to provide a platform for further analysis. Part II of the paper begins the exercise by identifying five potential trajectories for legal scholarship.

$4 \quad$ The most thorough treatment of which the author is aware is David Kennedy, When Renewal Repeats: Thinking Against the Box, 32 N.Y.U. J. INT'L. L. \& PoL. 335 (2000), though the purpose of this article was to discuss international law rather than legal scholarship generally.

5 On the volume of legal scholarship, see Peter Birks, The Academic and the Practitioner, 18 LEGAL STUD. 397, 398 (1998); Reinhard Zimmermann, Law Reviews: A Foray Through a Strange World, 47 EMORY L.J. 659, 692-93 (1998); Darla L. Daniel, Of Deckchairs, Icebergs and Gestalt Shifts: Unger, Kahn, and a Student of Contemporary Legal Thought, 72 U. COLO. L. REV. 851, 852 (2001). On the literature on legal scholarship, see Mary B. Beazley and Linda H. Edwards, The Process and the Product: A Bibliography of Scholarship About Legal Scholarship, 49 MERCER L. REV. 741 (1998).

6 David P. Bryden, Scholarship about Scholarship, 63 U. Colo. L. REV. 641, 641 (1992). 
The first of the five trajectories Part II discusses is based on the idea that knowledge "accumulates" as part of "progress" towards an improved understanding of the matters under study. The second is the concept of the "paradigm", derived from work done on the history and sociology of science. The third focuses on the idea that academic endeavor concerning law yields a "better" product over time since market forces are at work. The fourth is a "cyclical" thesis, grounded in the assumption that much legal scholarship revisits on a reoccurring basis themes previously explored. The fifth candidate is Sunstein's thesis that scholarly trends in law can be characterized in terms of fads and fashions. Part II concludes by offering a tentative hypothesis, this being that each of the five trajectories identified potentially influences academic writing on law to some degree. At the same time, none captures fully the dynamics at work and indeed there is some conflict between the various paths available.

In order to test the conjectures offered in part II, Part III of the paper undertakes a case study of a particular field, namely corporate law. The case study begins with an overview of theoretical corporate law scholarship, offered from historical and cross-border perspectives. Part III then assesses whether scientific methodology has had a substantial influence on how the relevant literature has evolved. After this, insights derived from the history and sociology of science will be relied upon to offer a précis of corporate law scholarship, together with a matching critique. This will be followed by an assessment whether a marketplace for ideas has helped to foster "better" academic writing on corporate law. Next, there will be discussion of whether a strong cyclical dimension is present. Part III concludes with 
an examination of the extent to which corporate law scholarship has evolved in accordance with Sunstein's account of fads and fashions.

Part IV offers a conclusion. One theme is that the corporate law case study set out in Part III lends support to the hypothesis developed in part II, namely that various dynamics - some in at least partial conflict - influence the path of legal scholarship. Another point made is that the test case was a fair one. Corporate law was chosen as the subject matter for a pragmatic reason: it is the author's chosen area of research. Still, as part IV will discuss, the attributes of this particular field conform sufficiently to the norm in legal scholarship to ensure that the case study was appropriate. Finally, it is acknowledged that the pluralist verdict this paper offers concerning potential trajectories will not be a fully satisfying one for those seeking definitive answers. ${ }^{7}$ Still, the point is made that some type of hedging appears inevitable (and prudent) since there is, as of yet, "no jurisprudence of legal scholarship".

Before proceeding, it is necessary to clarify a threshold issue, which is to define what qualifies as legal scholarship. ${ }^{8}$ Its precise boundaries are uncertain. ${ }^{9}$ For

$7 \quad$ For a criticism of "congenial pluralism", see JOHN C.P. GOLDBERG, TwENTIETH CENTURY TORT THEORY, 85-86 (Vanderbilt University Law School Law \& Economics Working Paper 02-15, 2002), forthcoming GEO. L.J, (2003).

$8 \quad$ There is a tendency to assume that everyone knows what is meant by scholarship in general and legal scholarship in particular: David Feldman, The Nature of Legal Scholarship, 52 MOD. L. REV. 498, 498 (1989).

$9 \quad$ Kenneth Lasson, Scholarship Amok: Excesses in the Pursuit of Truth and Tenure, 103 HARV. L. REV. 926, 935 (1990); Edward L. Rubin, Legal Scholarship, in A COMPANION TO PHILOSOPHY OF LAW AND LEGAL THEORY 562, 562 (Dennis Patterson ed., 1996). Legal dictionaries provide little assistance. Perhaps the most helpful guidance is offered by the BUTTERWORTHS AUSTRALIAN LEGAL DICTIONARY 681 (Peter E. Nygh and Peter Butt, eds., 1997) (saying legal theory refers "to any 
our purposes, though, it should be sufficient to say that legal scholarship constitutes the body of learning, and especially the academic research available, in the field of law. ${ }^{10}$ Under this definition, jurisprudence, which is concerned with questions regarding the nature of law, its general structure, its sources and so on, clearly qualifies. Theoretical legal scholarship - which implies the use of intellectual disciplines external to law to carry out research on its economic, social or political implications - does as well. ${ }^{11}$ This is also the case with academic writing on law that has an explicit policy objective, such as promoting law reform. Finally, "doctrinal" or "descriptive" publications, where the author seeks to organize and categorize legal rules ("doctrine") in a systematic fashion, can be categorized as legal scholarship. ${ }^{12}$ While the "internal" focus of legal research of this nature means that it cannot be

academic analysis of the law which requires a degree of abstraction from the principles stated in case and statute-based law").

$10 \quad C f$. Ronald Benton Brown, A Cure for Scholarship Schizophrenia: A Manifesto for Sane Productivity and Productive Sanity, 13 NovA L. REV. 39, 39 (1988).

An alternative formulation would be "the body of work produced by university professors who teach in programs that prepare their students for careers in law": Rubin, Legal Scholarship, supra note xx, at 562. This, however, is probably too narrow because the definition excludes publications by judges and lawyers. See Philip C. Kissam, The Evaluation of Legal Scholarship, 63 WASH. L. REV. 221, 22223 (1988); cf. Feldman, Nature, supra note xx, at 509. On the extent to which academic work done on law by academics in disciplines other than law qualifies as legal scholarship, see Rubin, Legal Scholarship, supra note xx, 562-63; Edward L. Rubin, Law And and the Methodology of Law, [1997] WIS. L. REV. 521, 522-23.

11 On this definition of theoretical legal scholarship and how it relates to writing about jurisprudence, see Brian R. Cheffins, Using Theory to Study Law: A Company Law Perspective, 58 CAMBRIDGE L.J. 197, 198 (1998).

12 Rubin, Legal, supra note $\mathrm{xx}$, at 564-66; Richard A. Posner, The Present Situation in Legal Scholarship, 90 YALE L.J. 1113, 1113-16 (1981). On various subcategories of doctrinal scholarship, see Kissam, supra note xx, at 230-35. 
readily classified as legal theory, ${ }^{13}$ doctrinal writing undoubtedly constitutes a core element of the research available in the field of law. ${ }^{14}$

\section{LEGAL SCHOLARSHIP TRAJECTORIES: AN OVERVIEW}

A. The "Cumulative" Model: "Progress" Towards "Truth"

"Progress" is a complex notion. ${ }^{15}$ For instance, even among those who have explicitly acknowledged its past influence on society, there is some doubt about the agent of change (e.g. human initiative vs. cosmic intervention) and about whether there will be similar momentum in the future. ${ }^{16}$ Still, to the extent progress occurs, its general direction is clear: betterment and improvement. ${ }^{17}$ Moreover, it is fair to say that the concept implies the steady accumulation of knowledge over time. ${ }^{18}$

13 Rubin, Legal, supra note xx, at 564-66.

14 Cheffins, Using Theory, supra note xx at 197; Michael Chesterman and David Weisbrot, Legal Scholarship in Australia, 50 MOD. L. REV. 709, 722-24 (1987); Richard Posner, Legal Scholarship Today, 115 HARV. L. REV. 1315, 1317, 1320 (2002).

15 Indeed, at least one author of a book on the subject has refrained from offering a definition: MARGARITA MATHIPOUlOS, HistORY AND PROGRESS - IN SEARCH OF THE EUROPEAN AND AMERICAN MIND 5 (1989) (saying that to "attempt to arrive at a conclusive definition of progress would be as presumptuous as trying to prove or disprove the existence of supernatural powers").

16 On these questions, see ChARLES VAN DOREN, THE IDEA OF PROGRESS 5-6, 13-15, 23, 31-32, 261-63 (1967).

17 VAN DOREN, supra note $\mathrm{xx}$, at 6; JOHN BAGNELL BURY, THE IDEA OF PROGRESS: AN INQUIRY INTO ITS ORIGIN AND GROWTH 2, 5 (1924).

18 VAN DOREN, supra note $\mathrm{xx}$, at 324, 333; ROBERT NISBET, HISTORY OF THE IDEA OF PROGRESS 5 (1980); Michael D. Birnhack, The Idea of Progress in Copyright Law, 1 Buff. InTELl. Prop. J. 3, 13-14 (2001). Still, there are some who contend that cumulativity may not be an essential element of progress. See, for example, 
Drawing these themes together, a first potential trajectory for legal scholarship is "cumulative" in nature, with the presumption being that academics will be making headway in addressing issues considered important. To elaborate, legal scholars, being mindful of existing controversies, build upon the work of their predecessors. Over time, outstanding issues are resolved and new insights are derived from those resolutions. ${ }^{19}$ Sustained intellectual enquiry can thus be expected to yield a "better" understanding of the topics under examination.

Natural science is the intellectual endeavor where the sort of accumulation of knowledge just described is thought of as taking place in its purest form. ${ }^{20}$ The classic conception of scientific understanding is that it improves as part of an unfolding story as prior knowledge is used as the foundation to improve our comprehension of the world. ${ }^{21}$ Scientists, under this view, "progress" towards the "truth" by relying on "scientific method", which constitutes objective enquiry founded on the safeguards of explicit theory-building, replication and corroboration. ${ }^{22}$

LARRY LAUDAN, BEYOND PositivisM AND RElativisM: THEORY, METHOD AND EVIDENCE 22-23 (1996).

19 Rubin, "Law And", supra note xx, at 526; Carl N. Edwards, In Search of Legal Scholarship: Strategies for the Integration of Science into the Practice of Law, $8 \mathrm{~S}$. CAL. INTERDISC. L.J. 1, 21 (1998).

20 Lawrence M. Friedman, The Law and Society Movement, 38 STAN. L. REV. 763, 766 (1986).

21 Marcello Pera, In Praise of Cumulative Progress, in CHANGES AND PROGRESS IN Modern SCIENCE 267, 267 (Joseph C. Pitt ed., 1985); Jan Beyea and Daniel Berger, Scientific Misconceptions Among Daubert Gatekeepers: The Need for Reform of Expert Review Procedures, 64 LAW \& CONTEMP. PROBS. 327, 330-31 (2001).

22 Edwards, supra note $\mathrm{xx}$, at 24; Nancy Levit, Listening to Tribal Legends: An Essay on Law and Scientific Method, 58 FordHAm L. Rev. 263, 266-72 (1989). See also Daubert v. Merrell Dow Pharmaceuticals 509 U.S. 579, 590 (1993), where 
Does legal scholarship "progress" in a manner akin to that attributed to scientific knowledge? The possibility it does merits exploration since various attempts have been made to characterize the analysis of law in scientific terms. Perhaps the most ambitious effort to depict the legal system as a body of scientifically-deducible principles was pioneered by Christopher Columbus Langdell, Dean of Harvard Law School in the late $19^{\text {th }}$ century. ${ }^{23}$ For Langdell and his disciples, law constituted an objective system defined by concrete, recurrent principles set down in decided cases. Scientific enquiry proceeded by extracting rules from judicial rulings and law "progressed" when a jurist or scholar discovered a previously unarticulated principle that made sense of a body of case law. The rise of the academic treatise, where authors sought to rationalize and rethink entire areas of doctrine, was a significant by-product of this sort of legal science. ${ }^{24}$

By the 1920s, the scientific approach to law advocated by Langdell was becoming unfashionable since American legal academics were rebelling against what was felt to be an unduly stale and technocratic conception of the legal system. ${ }^{25}$ Ironically, those academics who turned the tide against Langdell's intellectual project

Justice Blackman observed that "(s)cience...is a process for proposing and refining theoretical explanations about the world that are subject to further testing and refinement...."

23 On Langdell's version of legal science, see Levit, supra note xx, at 275-77; NeIl DuXbury, PATterns OF AMERICAN JuRISPRUdENCE, 14-24 (1995); ANTHONY T. Kronman, The Lost LAWYeR: FALling IdEALS OF THE LEGAL ProfESSION 170-75 (1993).

24 Robert W. Gordon, Lawyers, Scholars, and the "Middle Ground", $91 \mathrm{MICH}$. L. REV. 2075, 2079-80 (1993); LAWRENCE M. FRIEDMAN, AMERICAN LAW IN THE TWENTIETH CENTURY 490 (2002). 
were themselves favorably disposed towards judicious use of scientific methodology. Langdell's critics did not believe that law could be reduced to a set of internally consistent principles by the careful study of cases. Many, however, were "legal realists" who were optimistic that the proper application of the methods of social science, particularly empirical analysis, could yield reveal "the reality" of law. ${ }^{26}$ The most potent contemporary variant of this line of reasoning comes from the field of law and economics. ${ }^{27}$ One argument those who advocate the use of economic analysis to study law have made is that their brand of scholarship facilitates the accumulation of knowledge in a scientific fashion since empirically disprovable hypotheses are being produced and tested. $^{28}$

The scientific conception of law has had enduring appeal in other respects. ${ }^{29}$ In continental Europe, a strong belief that law is a system rather than merely a practical tool for structuring relations and solving conflicts underpins to this day a

25 DuXBURy, PATTERns, supra note xx at, 24-25, 36-37, 79; John Veilleux, The Scientific Model in Law, 75 GEO. L.J. 1967, 1977-78 (1987).

26 Kronman, supra note xx, 195-201; Morton J. Horwitz, THE TRANSFORMATION OF AMERICAN LAW 1870-1960: THE CRISIS OF LEGAL ORTHODOXY 209-11 (1992); Brian Leiter, Is There an “American” Jurisprudence?, 17 OXFORD J. OF LEGAL ST. 367, 377-78 (1997).

27 KRONMAN, supra note xx, 225-32, 240.

28 Posner, Present, supra note xx, at 1121-22; Jason Scott Johnston, Law, Economics, and Post-Realist Explanation, 24 LAW \& SoC'Y REV. 1217, 1231-32 (1990); Jonathan R. Macey, Law and the Social Sciences, 21 HARV J. L. \& PUB. POL'Y 171, 172-73 (1997).

29 Posner, Present, supra note xx, at 1120-21; Darla L. Daniel, Of Deckchairs, Icebergs and Gestalt Shifts: Unger, Kahn, and a Student of Contemporary Legal Thought, 72 U. CoLO. L. REV. 851, 866-67 (2001). 
strong faith in the idea of legal science. ${ }^{30}$ Also, despite the doubts cast upon Langdell's approach to law, Anglo-American observers still sometimes make the case that the quality of legal scholarship and judicial decision-making would improve if academics and judges adopted scientific techniques and principles on a consistent and conscientious basis. ${ }^{31}$ Moreover, supported by pleas for more empirical legal scholarship, the production of research which uses statistical data to test defined hypotheses is on the rise. ${ }^{32}$ This latter trend has, in turn, led some to proclaim that the study of law is becoming more science-like. ${ }^{33}$

Still, while the notion that our understanding of law can be improved via the proper application of scientific method has had enduring appeal, the extent to which academic learning concerning law accumulates in a manner akin to scientific knowledge should be kept in perspective. One caveat involves the cross-border communication of ideas. With the physical and natural sciences, theory-building and theory-testing can occur through the medium of a transnational scholarly

30 FriedmAn, AMERICAN, supra note xx, at 501; Franz Werro, Notes on the Purpose and Aims of Comparative Law, 75 TUL. L. REV. 1225, 1229 (2001). Note, though, that equating the continental version of legal science with natural science is not entirely appropriate: Fletcher, supra note xx, at 988-89.

31 See, for example, Veilleux, supra note xx; Peter Ziegler, A General Theory of Law as a Paradigm for Legal Research, 51 MoD. L. REV. 569 (1988); Peter A. Alces, Contract Reconceived, 96 Nw. U. L. REV. 39, $95-97$ (2001).

32 Michael Heise, The Past, Present, and Future of Empirical Legal Scholarship: Judicial Decision Making and the New Empricism, [2002] U. ILL. REV. 819, 821, 824-26, 831.

33 Thomas S. Ulen, A Nobel Prize in Legal Science: Theory, Empirical Work, and the Scientific Method in the Study of Law, [2002] U. ILL. REV. 875, 909-10, 91216. 
community. ${ }^{34}$ This is because the subject matter of research (e.g. the prediction of earthquakes) conducted in a particular country will typically be understood by researchers everywhere and investigations which are conducted can generally be evaluated by experts around the world. Matters are different with law, since legal scholars tend to write only about their own legal system and only for those acting within that system. ${ }^{35}$ Moreover, there are no globally accepted theories concerning the role of law and the functioning of the legal system, so even legal scholarship that is explicitly cross-border in orientation will necessarily have an audience that is to some degree jurisdictionally specific. ${ }^{36}$

Another important distinction between science and legal studies is that the method of enquiry typically differs. ${ }^{37}$ Scientists consciously seek to assimilate, verify and expand upon the work of others in the field. In contrast, testing established theoretical constructs is not necessarily a core feature of legal scholarship. Instead, it has a reactive quality, in the sense that the purpose often is to address timely issues arising on an ad hoc basis (e.g. a recent case or statutory enactment).

\footnotetext{
$34 \quad$ Id. at $894-95$.

$35 \quad I d ., 895$.

$36 \quad I d$.

37 Edwards, supra note xx, at 21-22; Rubin, Law And, supra note xx, at 550; Terence Daintith, Legal Research and Legal Value, 52 MoD. L. REV. 352, 357 (1989); Todd D. Rakoff, Introduction, 115 HARV. L. REV. 1278, 1285-86 (2002).
} 
Also important is that academic lawyers may have an explicitly normative inclination that is largely absent from the sciences. ${ }^{38}$ Scientists are not simply disinterested searchers for the truth but rather are individuals engaged in a human activity which can have an underlying social or political agenda. ${ }^{39}$ Nevertheless, the discourse of scientists is couched in value-free terms; good work within a particular field is that which accounts for observable phenomena. In contrast, legal scholarship quite often akin is akin to advocacy, with the author critiquing court decisions or legislative policies with objective of putting the law at the service of an admired cause. $^{40}$ As Edward Rubin, a US law professor, has said about law:

\footnotetext{
"The entire field crackles with normativity, and it is this characteristic that renders the scientific concept of validity so unhelpful as a basis for evaluation."41
}

Or as John Kramer, another law professor, has frankly admitted with respect to his own scholarship:

Edwards, supra note xx, at 23-26; Rubin, Law And, supra note xx, at 524-28, 542; Michael J. Graetz and Charles H. Whitbread, Monrad Paulsen and the Idea of a University Law School, 67 VA. L. REV. 445, 455 (1981).

39 Tom Wilkie, Science is for Everyone, Whatever They Try to Tell You, INDEPENDENT, March 25, 1995, at 15.

40 Friedman, AMERICAN, supra note xx, at 501; Roger C. Cramton, Demystifying Legal Scholarship, 75 GEO. L.J. 1, 6-8 (1986); Rebecca S. Eisenberg, The Scholar as Advocate, 43 J. LEGAL EDUC. 391, 394 (1993); Graham Brown, Should Law Professors Practice What They Teach?, 42 S. TEX. L. REV. 316, 335 (2001).

41 Edward L. Rubin, On Beyond Truth: A Theory for Evaluating Legal Scholarship, 80 CAL. L. REV. 889, 904 (1992). 
"I did not pursue truth wherever it might lead. I pursued more food stamps, less hunger (and) the end of the impoundment of funds for the Women, Infants, and Children feeding program". ${ }^{42}$

To the extent that this attitude is prevalent generally among legal academics, it is unrealistic to expect legal scholarship to display the general pattern of cumulative knowledge so commonly associated with science. ${ }^{43}$

What about law and economics scholarship, with its scientific pretensions?

Even here, it cannot be taken for granted that the academic literature meets the strict standards of verification and reliability associated with science. Doubts exist about whether economics itself is a discipline where scientific methodology is properly invoked and knowledge accumulates. In particular, economists stand accused of accepting and applying too readily the contestable assumption that economic behavior is the consequence of rational choices governed by self-interest. ${ }^{44}$ Correspondingly, claims that law and economics advances our understanding of legal topics in a scientific manner must remain at best controversial. ${ }^{45}$

$42 \quad$ John R. Kramer, Comment on Rebecca Eisenberg's "The Scholar as Advocate”, 43 J. LEGAL EDUC. 401, 404 (1993).

43 Rubin, Law And, supra note xx, at 540-41.

44 John Pheby, Methodology and Economics: A CRitical InTROdUCtion 32-36 (1988); Daniel M. Hausman, Kuhn, Lakatos and the Character of Economics, in New Directions in Economic Methodology 195, 208-10 (Roger E. Backhouse ed., 1994); Gregory S. Crespi, The Mid-Life Crisis of the Law and Economics Movement: Confronting the Problems of Nonfalsifiability and Normative Bias, 67 Notre DAME L. ReV. 231, 232-33, 237-42 (1991).

45 For examples of those who have cast doubt on the scientific credentials of law and economics, see Levit, supra note xx, at 282-85; Mark Cooney, Why is Economic Analysis So Appealing to Law Professors?, 45 STAN. L. REV. 2211, 2230 (1993); 


\section{B. Paradigm Shifts: Kuhn and Legal Scholarship}

While the application of scientific methodology may well not be a hallmark of legal scholarship, even if it was, characterizing the evolution of academic writing on law in cumulative terms might still be inappropriate. The reason is that the received wisdom concerning the development of scientific knowledge may be misconceived. The orthodox view is that our understanding of science accumulates by way of objective analysis founded on the safeguards of replication and corroboration. In fact, however, even within the natural or physical sciences it cannot be taken for granted that there is "progress" towards the "truth" by reliance on "scientific method". This is because work done from an historical and sociological angle has cast doubt on the conventional wisdom concerning the accumulation of scientific knowledge. ${ }^{46}$

Thomas Kuhn has offered the most influential reappraisal of scientific endeavor through the invocation of terminology such as "paradigms" and "normal science". ${ }^{47}$ Law has certainly not been immune from Kuhn's influence; legal academics have on many occasions borrowed from his work to describe trends in the

Mark V. Tushnet, Law, Science, and Law and Economics, 21 HARV J. L. \& PuB. PoL'Y 47, 51-52 (1997). For a response, see Thomas S. Ulen, The Prudence of Law and Economics: Why More Economics is Better, 26 CUMB. L. REV. 773, 788-93 (1996).

You Can't Follow the Science Wars Without a Battle Map, ECONOMIST (London), December 11, 1997, at 109, 109-10.

47 Kuhn's seminal work was ThE STRUCTURE OF SCIENTIFIC REVOLUTIONS (3rd ed. 1996). The book has sold more than a million copies since its initial publication and it has been described as "the most influential academic work of the second half of the twentieth century": Mark Blaug, Book Review, 33 Hist. POL. ECON. 855, 855 (2001). 
literature. ${ }^{48}$ It is appropriate, therefore to consider whether the trajectory of legal scholarship can be characterized appropriately in "Kuhnian" terms.

According to Kuhn, ${ }^{49}$ within a given field, matters begin in a "preconsensus", "immature" or "pre-paradigm" phase. ${ }^{50}$ This means there is competition between intellectual schools addressing the same issues from different, mutually incompatible standpoints. The field subsequently comes together when work is produced that is sufficiently convincing to persuade members of existing schools to defect and to attract the next generation of academics. Once a consensus is in place that is focused on the dominant "paradigm" or "disciplinary matrix", ${ }^{51}$ researchers are spared the incessant and distracting re-examination of first principles. Instead, they can proceed with confidence to solve "puzzles" by reference to the dominant mode of thought. ${ }^{52}$

48 To illustrate, a search of Westlaw's "JLR" directory conducted in July 2003 with the query “'Thomas Kuhn' \& paradigm” yielded 555 documents. This electronic database has wide coverage of U.S. law reviews extending back to the early 1980s.

49 It is difficult to do justice to Kuhn's work when summarizing it, in large part because Kuhn qualified many of his assertions after the first edition of THE StRUCTURE OF SCIENTIFIC REVOlUtions (1962). On this pattern, see Blaug, Book Review, supra note xx, at 855. For a thorough overview of Kuhn's work, see PAUL Hoyningen-Heune, ReConstructing SCIENTIFIC REVOlutions: ThOMAS S. KUHN'S PHILOSOPHY OF SCIENCE (1993). For a succinct, if somewhat critical summary, see BRENDAN LARVOR, LAKATOS: AN INTRODUCTION 37-44 (1998).

50 KUHN, supra note xx, chapter 2.

51 The shift away from the "paradigm" terminology to "disciplinary matrix" was an example of Kuhn qualifying his basic concepts as time progressed. See KuHN, supra note xx, at 182; Blaug, Book Review, supra note xx, at 855.

$52 \quad$ KUHN, supra note xx, chapter 4. 
Such "mop-up work" within a "mature" field of research is known as "normal science". 53

Kuhn noted that those working in accordance with the precepts of "normal science" will periodically find inexplicable "anomalies" that are irreconcilable with the dominant paradigm. ${ }^{54}$ Over time, he said, an accumulation of serious anomalies can seriously destabilize the existing consensus and eventually build to a crisis. ${ }^{55} \mathrm{~A}$ fresh competition of ideas will then ensue that could either leave the existing paradigm intact or culminate in a "scientific revolution" that establishes a new consensus within the discipline. ${ }^{56}$ If a "paradigm shift" does occur, normal science will ultimately recommence under the new worldview, setting the stage for the cycle to repeat itself. ${ }^{57}$

According to Kuhn, such "paradigm shifts" do not yield the accumulation of knowledge in the manner traditionally associated with scientific progress. Instead, since the preconceptions underlying successive traditions of normal science are radically different, discerning how the relevant paradigms are interrelated is highly problematic. In other words, since comparative evaluation cannot be effected by a neutral, universal set of rules, disciplinary matrixes tend to be "incommensurable". 58

\footnotetext{
$53 \quad I d$., chapter 3.

$54 \quad I d$, , chapter 6.

$55 \quad$ Id., chapter 7.

$56 \quad$ Id. at 84.

$57 \quad I d$, chapters $10,12$.

$58 \quad I d$ at $102,110,112,147-51$.
} 
Correspondingly, no a priori assumptions can be made as to whether a paradigm shift constitutes a move towards the "truth" in any objective sense. ${ }^{59}$ All that can be said is that the relevant academic community is working within an intellectual mindset that is addressing more successfully the issues deemed pertinent and topical. ${ }^{60}$

Kuhn's argument that "progress" can be explained by reference to "normal science" and "paradigm shifts" proved infectious outside the realm of natural and physical sciences. ${ }^{61}$ For instance, social scientists have frequently discussed their own particular fields with reference to Kuhn's insights. ${ }^{62}$ Also, politicians have drawn upon his ideas and even popular journalism is replete with references to "paradigms". ${ }^{63}$ Hence, it should not be surprising that legal academics have relied on his theories to explain trends in legal scholarship. It has been said, for instance, that

“...the legal community, especially the legal academy, bears significant parallels to the scientific community as Kuhn describes it. Both rely on standardized textbooks for initiation into the profession; both enjoy substantial

$59 \quad I d$. at 170-73, 206-7. Kuhn developed his thoughts further in other published work. For a summary, see HoYnINGEN-HEUnE, supra note xx, 263-64.

60 While many have inferred from Kuhn's work that one paradigm is just as good as another, it is open to question whether he believed this: Ulen, Nobel, supra note $\mathrm{xx}, 885$.

61 Louis Menand, Undisciplined, WILSON Q., Autumn 2001, 51, 58-59.

62 Esther-Mirjam Sent, Thomas Kuhn: The Wrong Person at the Wrong Time, 63 REV. PoL. 390, 390 (2001).

63 Robert Fulford, Paradigm: Putting the " $P$ " Word in Perspective, GLOBE \& MAIL, June 5, 1999, at D9; Wade Roush, Dwarf Standing on Giants, TECH. REV., Sept./Oct. 2000, 126 at 126. 
insulation from the laity; both concern day-to-day puzzle solving; and both display quite similar internal communal structure."64

Moreover, Kuhn's notions of normal science, paradigms and so on have been relied upon to describe intellectual trends in a wide range of areas of the law, including contracts ${ }^{65}$ immigration, ${ }^{66}$ civil procedure,${ }^{67}$ and race relations. ${ }^{68}$

Despite the borrowing from Kuhn, it is open to question whether law is a context to which his approach can be fruitfully extended. Kuhn himself generally sought to distance himself from efforts to use his work outside the scientific field ${ }^{69}$ and there is reason to believe that this sort of skepticism is appropriate with respect to

64 Steven L. Winter, "Bull Durham” and the Uses of Theory, 42 STAN. L. REV. 639, 670, n. 162 (1990).

65 Alces, Contract, supra note xx, at 79-87.

66 George A. Martinez, Race and Immigration Law: A Paradigm Shift [2000] U. ILL. L. REV. 517.

67

Jeffrey W. Stempel, New Paradigm, Normal Science, or Crumbling

Construct? Trends in Adjudicatory Procedure and Litigation Reform, 53 BROOK. L. REV. 659 (1993).

68

Juan F. Perera, The Black/White Binary Paradigm of Race: The "Normal Science” of American Racial Thought, 85 CAL. L. REV. 1213 (1997).

69 Gordon McOuat, The Mistaken Gestalt of Science Studies: Steve Fuller Takes on Kuhn, 36 CAN. J. HisT. 523, 523 (2001). Kuhn himself said:

"I used to say that if you go through college in science and mathematics you may well get your bachelor's degree without having been exposed to the Structure of Scientific Revolutions. If you go through college in any other field you will read it at least once. That was not altogether what I wanted (quoted in Blaug, Book Review, supra note xx at 855)."

See also KUHN, supra note $\mathrm{xx}$, at 208-9. 
legal scholarship. ${ }^{70}$ We have seen that traditions such as explicit theory-building, empirical testing, replication and review seem to be lacking with legal scholarship. ${ }^{71}$ The discrepancies between scientific methodology and the study of law imply, in turn, that using what Kuhn had to say about science to understand legal scholarship better is a problematic leap in logic. ${ }^{72}$

Also noteworthy is that academic writing about law tends to have a strong normative and pragmatic dimension that is absent from scientific publications. ${ }^{73}$ To the extent that legal scholarship simply involves an interchange between those with differing opinions on foundational issues, legal studies seemingly lack the sort of consensus that marks out a "mature" field of research. In other words, legal academics may not have moved beyond the "pre-paradigm" or "immature" phase and developed the tight research consensus required for "normal science". ${ }^{74}$ If this is an accurate prognosis, then it is inappropriate to think about the evolution of legal scholarship in Kuhnian terms.

C. Market Forces and Progress

70 Note, though, that Kuhn explicitly identified the use of precedent in judicial decisions as an example of paradigm elaboration: KUHN, supra note xx, at 23.

71 Supra note $\mathrm{xx}$ and accompanying text.

72 Ziegler, supra note $\mathrm{xx}$, at 573-74; Stempel, supra note $\mathrm{xx}$, at 699.

73 Supra note $\mathrm{xx}$ and related discussion.

$74 \quad$ Rubin, On Beyond, supra note xx, at 895-96; Daintith, supra note xx, at 35657; Charles W. Collier, Interdisciplinary Legal Scholarship in Search of a Paradigm, 42 DUKE L.J. 840, 842-44 (1993) (noting, though, that legal scholarship in the U.S. may have formerly possessed a stable paradigm oriented around doctrinal analysis). 
A contentious inference that can be drawn from Kuhn's work is that science does not provide a platform for a move towards the "truth" in any objective sense. The concern in this instance is that the notion that successive scientific theories are incommensurable lends support to a corrosive form of "anything goes" relativism. ${ }^{75}$ A debate influenced by the same intellectual dynamics has occurred in relation to legal scholarship, with the result being much heated discussion about whether the "quality" of what is published can be evaluated in accordance with any sort of neutral criteria. ${ }^{76}$ Regardless, at this point parallels that might be drawn between academic writing on law on the one hand and scientific methodology or Kuhn's work on the other will be set to one side. ${ }^{77}$ Instead, there will now be analysis of why academic writing about law, despite shaky scientific credentials, might still "progress".

It must be acknowledged that, in the present context, the possibility of meaningful improvement over time cannot be taken for granted. Instead, so long as debates about relativism remain unresolved, presuming that legal scholarship can actually become "better" is an inherently contentious step to take. To move the analysis forward, however, we will assume that meaningful distinctions can in fact be

75 See LAUDAN, supra note xx, 8-9, 14-17 (1996); ECONOMIST, supra note xx, at 110. For more background on charges of relativism and Kuhn's response, see HOYNIGEN-HEUNE, supra note Xx, 259-64.

76 Rubin, On Beyond, supra note xx; Joseph W. Singer, The Player and the Cards: Nihilism and Legal Theory, 94 YALE L.J. 1, 33-35 (1984); John S. Elson, The Case Against Legal Scholarship or, If the Professor Must Publish, Must the Profession Perish, 39 J. LegAL Educ. 343, 356-57, 362-64 (1989).

77 These topics can properly be set aside together. This is because, if it is inappropriate to think of legal scholarship in Kuhnian terms, debates about relativism within the scientific realm become largely irrelevant to legal scholarship. See Ernest J. Weinrib, Legal Formalism: On the Immanent Rationality of Law, 97 YALE L.J. 949, 964 (1988). 
made on the basis of criteria such as "quality" or "truth" 78 For our purposes, then, there is scope for progress within legal scholarship. What might drive matters in this direction if scientific methodology is not invoked on a systematic basis? An answer worth considering is that market-oriented dynamics act as the catalyst for a move towards "better" legal scholarship. ${ }^{79}$

Essentially, the hypothesis under analysis here is that a beneficial competition among alternatives occurs in a legal scholarship market, thus yielding an improved understanding of law. ${ }^{80}$ Legal scholar Herbert Hovenkamp has said of economics:
"The market for economic ideas is no different from the market for products or services. When a demand appears, someone will try to supply it, from whatever source. $^{81}$

Perhaps the same occurs with legal scholarship. ${ }^{82}$

78 This follows the approach adopted by Kissam, Evaluation, supra note xx, at 254-55. Still, it must be acknowledged that the working assumption is a somewhat heroic one, since entire volumes have been devoted to ascertaining the precise content of "truth". See, for example, RichaRd CAMPBELL, TRUTH AND HISTORICITY (1992).

79 On the more general proposition that the operation of market forces can yield progress, see VAN DOREN, supra note xx, 95-97; NISBET, supra note xx, 187-93, 299 (focusing primarily on the work of Adam Smith).

80 See George L. Priest, The Growth of Interdisciplinary Research and the Industrial Structure of the Production of Legal Ideas: A Reply to Judge Edwards, 91 MicH. L. REV. 1929, 1940-42 (1993); Robert C. Ellickson, The Market for "LawAnd” Scholarship, 21 HARV J. L. \& PUB POL'y 157, 164-70 (1997); Erwin Chereminsky and Catherine Fisk, In Defense of the Big Tent: The Importance of Recognizing the Many Audiences for Legal Scholarship, 34 TULSA L.J. 667, 675-76 (1999). (1991). 
To elaborate, with a conventional market for products or services, there are forces of supply and demand. With respect to legal scholarship, the "supply side" consists of researchers who write about law. The "demand side" is composed of those who "consume" what is written, such as legal academics, editors of law reviews, legal publishers, practicing lawyers, law students and judges. The suppliers in the legal scholarship market have various incentives to produce "quality" academic work. ${ }^{83}$ These include the prospect of job security (tenure), nonpecuniary rewards (peer esteem and satisfaction derived from influencing changes in the law), ${ }^{84}$ and financial benefits (increased royalties, better job offers and enhanced consulting opportunities).

Consumers,for their part, can discipline suppliers in various ways. Manuscripts submitted for publication can be accepted or rejected. ${ }^{85}$ Books can be purchased or left to sit on the shelves. "Quality" publications can be cited with approval in print or discussed favorably as part of hiring or promotion exercises. ${ }^{86}$

82 For background, see sources cited supra note xx as well as George L. Priest, Triumphs or Failings of Modern Legal Scholarship and the Conditions of its Production, 63 U. COL. L. REV. 725 (1992).

83 See Lasson, supra note $\mathrm{xx}$, at 948-49; Chereminsky and Fisk, supra note $\mathrm{xx}$, at 677-78.

84 "(V)anity is the occupational disease of the academic": David Luban, Legal Scholarship as a Vocation, 51 J. LEGAL EdUC. 167, 171 (2001) (quoting Max Weber). 85 The criteria applied will vary depending on the intended audience: Banks McDowell, The Audience for Legal Scholarship, 40 J. LEGAL EDUC. 261, 266-68 (1990).

86 Note, though, that consumer preferences in the legal scholarship market are not homogeneous: Michael D. McClintock, The Declining Use of Legal Scholarship by Courts: An Empirical Study, 51 OKLA. L. REV. 659, 686-87 (1998). 
Finally, sloppy work or misguided intellectual frolics can be criticized or simply ignored. ${ }^{87}$

There certainly are those who believe that market discipline has caused legal scholarship to improve and progress over time. ${ }^{88}$ Still, potential flaws with the market for legal scholarship, such as it is, must be acknowledged. ${ }^{89}$ For instance, concerns have been raised that outside consulting and the underwriting of research by special interest groups diminish the objectivity of law professors and correspondingly have a corrupting influence on the quality of legal scholarship. ${ }^{90}$ Moreover, there is a risk that once academics have completed whatever probationary period they must serve before becoming permanent members of a faculty and are otherwise content with their current status in the job market, they will lack meaningful incentives to produce scholarship of a high standard..$^{91}$ On the other hand, empirical evidence on the impact of the awarding of tenure on academic productivity indicates that implicit incentives

87 On the high percentage of articles in U.S. law reviews which are unread, see Gava, supra note $\mathrm{xx}$, at 458-60; Rhode, supra note $\mathrm{xx}$, at 1331.

88 See sources cited infra notes xx to xx as well as Robert W. Gordon, Lawyers, Scholars, and the "Middle Ground”, 91 MicH. L. REV. 2075 (1993); Richard A. Posner, The Deprofessionalization of Legal Teaching and Scholarship, $91 \mathrm{MICH}$. L. REV. 1921, 1925 (1993).

$89 \quad$ Sunstein, supra note xx, at 1254; Bruce A. Ackerman, The Marketplace of Ideas, 90 YALE L.J. 1131, 1139-40 (1981).

90 Eisenberg, Scholar, supra note xx, Richard B. Schmitt, Rules May Require Law Professors to Disclose Fees, WALl St. J., Jan. 31, 2000, at B1; Richard Lippitt, Intellectual Honesty, Industry and Interest Sponsored Professorial Works, and Full Disclosure: Is the Viewpoint Earning the Money, or is the Money Earning the Viewpoint?, 47 WAYNE L. REV. 1075, 1081-85, 1094-95 (2001).

91 Zimmerman, Law, supra note xx, at 692; David L. Gregory, The Assault on Scholarship, 32 WM. \& MARY L. REV. 993, 996-7, 1001 (1991). 
such as the desire to retain the respect of peers may operate as a sufficient check against "slacking". 92

Turning to the demand side, there again are potential flaws with the market. For instance, consumers of academic work may be too busy to evaluate the product properly. Also, law review editors and publishers will not always have the expertise required to detect quality. ${ }^{93}$ Moreover, even if those choosing what will appear in print are knowledgeable, they may lack incentives to take seriously the priorities of those who actually read legal scholarship. For instance, the fact that most of America's law reviews receive hefty subsidies from their host schools means that for the students who edit these journals catering to the preferences of the potential audience does not have to be the top priority. ${ }^{94}$

Whatever the precise cause, the "end product" does have strong critics. Some wonder, for instance, if legal scholarship "is at best an other-worldly irrelevance and at worst a radical and doomed narcissism". 95 Others dismiss much of "what passes for legal 'research'...as antediluvian". ${ }^{96}$ In the United States, at least, student-run law

$92 \mathrm{Si} \mathrm{Li}$ and Hui Ou-Yang, Incentives, Performance, and Academic Tenure, unpublished working paper (2003) (providing data indicating that the number of publications and number of citations generated by economists at leading American universities is much the same both before and after tenure).

93 Ellickson, Market, supra note xx, at 169 (raising the possibility to cast doubt upon it).

94 Rhode, supra note xx, at 1356; Priest, Triumphs, supra note xx, at 726-29.

95 Peter Goodrich, Of Blackstone's Tower: Metaphors of Distance and Histories of the English Law School, in WHAT ARE LAW SchOOLS For? 59, 66 (Peter B.H. Birks, ed., 1996). 
reviews are primary targets for critics of legal scholarship. For instance, there allegedly are too many articles published, ${ }^{97}$ though defenders of the journals say this is an unavoidable price associated with the production of legal scholarship which is of high quality. ${ }^{98}$ Moreover, the output is regularly chastised for an absence of eloquence and elegance, unnecessary length and documentation, a lack of originality and excessive insularity. ${ }^{99}$ The upshot is that a market for legal scholarship can potentially foster quality output but it remains open to question whether the forces of supply and demand are potent enough to ensure that "progress" is the dominant outcome.

\section{Intellectual Cycles}

To this point, we have seen that legal scholarship can potentially be characterized as the accumulation of knowledge, as the subject matter of "paradigms" and as the product of an intellectual marketplace. On the other hand, there is reason to believe that the evolution of academic writing on law cannot be accounted for purely in terms of models appropriate for scientific literature and is not necessarily the product of a beneficial interaction of forces of supply and demand. Correspondingly,

$97 \quad$ Gava, supra note xx, at 461, 465; Rhode, supra note xx, at 1331; Neil Duxbury, When Trying is Failing: Holmes's “Englishness”, 63 BROOK. L. REV. 145, 149-50 (1997). Not everyone agrees. See, for example, Gregory, Assault, supra note $\mathrm{xx}$, at 998 .

$98 \quad$ Posner, Deprofessionalization, supra note xx, at 1928 (making this observation while characterizing the production of legal scholarship in sociobiological terms).

99 See, for example, Lasson, supra note $\mathrm{xx}$, at 942-48; Rhode, supra note $\mathrm{xx}$, at 1333-36, 1339-42; Zimmerman, supra note xx, at 677-81, 689-90; FRIEDMAN, supra note $\mathrm{xx}$, at 497-99. For an overview of the criticisms leveled against American law 
it is appropriate to consider additional factors that might govern the trajectory of legal scholarship. A possibility that merits consideration is a cyclical dimension. The idea is that, to at least some degree, the academic analysis of legal issues constitutes a continuing conversation about pivotal questions. ${ }^{100}$ As Neil Duxbury, a U.K. academic, has observed in a book on trends in American jurisprudence:

"Ideas - along with values, attitudes and beliefs - tend to emerge and sometimes they are revived and refined. But rarely do we see them born or die. History is not quite like that." 101

The possibility that legal scholarship has a cyclical quality has been acknowledged in various contexts. Some observations on the point relate to general trends. For instance, Duxbury says the received wisdom concerning American legal thought is that there has been a pendulum swing back and forth between "formalistic" analysis (e.g. the legal science associated with Langdell and the policy-oriented Legal Process school of the 1950s and 1960s) and "realistic" views (e.g. the "legal realism" that supplanted "Langdellism" and the critical legal studies movement of the 1980s). ${ }^{102}$ Also, in a 1993 law review article entitled "Plus ça Change", Paul Brest said that

reviews, see Richard S. Harnsberger, Reflections About Law Reviews and Legal Scholarship, 76 NEB. L. REV. 681, 687-91, 701-3 (1997).

$100 \quad$ Gava, supra note $\mathrm{xx}$, at 446.

101 DUXBURY, supra note $\mathrm{xx}$, at 2-3.

102 Id. at 2-3. 
“(t)aking everything into account, a law student who fell asleep in 1963 and awoke in 1993 would not be astonished by his new surrounds. If he had fallen asleep holding a law review - the soporific power was no weaker in those days - the nature and language of some of the articles would bewilder him, but he would find much that is familiar". ${ }^{103}$

The same point of view has been echoed in relation to particular aspects of law. Lawrence Friedman, a founder of the interdisciplinary approach to law known as the law and society movement, has said that with it "(t)he work does not, in general, build or grow; it travels in cycles and circles, round and round". ${ }^{104}$ With respect to law and economics, Mark Tushnet observed in a 1998 article entitled "Everything Old is New Again" that a "new Chicago school" that focuses on the relation between informal social conventions ("norms") and law is an unintentional intellectual descendant from venerable traditions in sociology and anthropology. ${ }^{105}$ David Kennedy, an international law academic, referred in an article published in 2000 to a "pendulum movement" in his discipline and said that "(f)or the past hundred and more years, the modes of both criticism and reform have remained remarkably stable". ${ }^{106}$ Similarly, David Clark, a comparative lawyer, said of his field in 2001 that “(a)lthough comparative law research has spread to countries in which it did not exist

103 Paul Brest, Plus ça Change, 91 Mich. L. REv. 1945, 1950 (1993).

104 Lawrence M. Friedman, The Law and Society Movement, 38 STAN. L. REV. 763, 766 (1986). For background on the law and society movement and Friedman's contribution to it, see DUXBURY, supra note $\mathrm{xx}$, at 440-45.

105 Mark Tushnet, "Everything Old is New Again”: Early Reflections on the "New Chicago School” [1998] WISC. L. REV. 579, 579, 584-85.

$106 \quad$ Kennedy, supra note $\mathrm{xx}$, at 340, 376. 
in 1900, and the diversity and quality of writing has improved, the basic ideas were already in place a century ago". ${ }^{107}$

Though Clark acknowledged that comparative law scholarship improved in certain respects during the $20^{\text {th }}$ century, the notion that the trajectory of ideas is cyclical has a distinctly pessimistic connotation. Essentially, the possibility of linear advancement seems largely foreclosed if a "rise and fall" pattern predominates. ${ }^{108}$ Answers to perennial questions may admittedly differ over time. Still, this does not mean there has been "progress". Instead, as part of a pendulum-like movement, a mode of thought that is dominant at a particular point in time might simply be a candidate for replacement by its polar opposite.

Is such pessimism justified with legal scholarship? Academic debates about law often do have a recurrent dimension. Still, is it true that there is "nothing new under the sun"? ${ }^{109}$ It seems unlikely. One consideration is what former British Prime Minister Harold Macmillan referred to as "events, dear boy, events". ${ }^{110}$ With academic disciplines oriented to foundational texts, such as philosophy and literature,

107 David S. Clark, Nothing New in 2000? Comparative Law in 1900 and Today, 75 TUL. L. REV., 871, 894 (2001).

108 VAN DOREN, supra note $\mathrm{xx}$, at 21-22, 113-14; Birnhack, Idea, supra note xx, at 9. There is a more pessimistic alternative - regression - which is not considered here. On "theories of regress", see VAN DOREN, supra note xx, at 114-16, 119-21.

109 On the link between this phrase and a cyclical trajectory of ideas, see VAN DOREN, supra note $\mathrm{xx}$, at 114.

110 For one of the many of sources citing the quote, see John Willman, Turning Back the Hands of Time, Fin. TIMES (London), October 19, 2002, FT Weekend, at 4. 
there inevitably will be some tendency to revisit issues previously explored. ${ }^{111}$ On the other hand, with legal studies, the topics for debate are unlikely to remain entirely fixed and constant since law evolves in response to changing social circumstances. Academics, in turn, are placed under an onus to adjust since good timing is often a core attribute of successful legal scholarship. ${ }^{112}$ Correspondingly, when there is a major change to the law, or an entirely new field of legal regulation emerges, the parameters for debate necessarily shift.

Even if current events are taken out of the equation, it still remains open to question whether legal scholarship has a strongly cyclical dynamic. For instance, with the trajectory of American legal thought, Duxbury has explicitly challenged the pendulum swing account. ${ }^{113}$ Indeed, doubts have in fact been cast on whether there are any serious proponents of this version of history. ${ }^{114}$ Moreover, Brest's "plus ça change, plus ça meme chose" appraisal of the academic study of law in the concluding decades of the $20^{\text {th }}$ century is not shared universally. Some have argued that, because of a shift away from doctrinal work in favor of interdisciplinary analysis, there was a net decline in the social value of legal scholarship. ${ }^{115}$ Others, however, think that the

111 Still, progress arguably can occur even in such fields. See, for example, VAN DOREN, supra note $\mathrm{xx}$, at 331-32.

112 Jim Chen and David Schultz, Force Majeure in Legal Scholarship, 14 ConST. COMMENT. 427, 428 (1997).

113 DUXBURY, supra note $\mathrm{xx}$, at 2-3.

114 Brian Leiter, Is There an “American” Jurisprudence?, 17 OXFORD J. LEGAL STUD. 367, 372 (1997).

115 See, for example, Harry T. Edwards, The Growing Disjunction Between Legal Education and the Legal Profession 91 MicH. L. REV. 34 (1992) (as characterized by Posner, Deprofessionalization, supra note xx, at 1925). 
switch in emphasis was a distinct improvement. For instance, a Canadian law professor observed in 1986 that "(l)egal scholarship has changed dramatically in this century" and "has dramatically increased what we know about the way law actually works". ${ }^{116}$ A leading US legal academic offered the same verdict a few years later:

"The last quarter century has been a golden age for American legal scholarship. We have seen a profusion of scholarly publication whose range, ambition and quality is without compare in the history of American law schools.",117

Similar sentiments have been expressed to particular subject areas. For instance, while some comparative lawyers worry that the core ideas in the field have been around for decades, others are more upbeat. As the president of the International Academy of Comparative Law observed in 2001

"Methods have been refined, instruments have been developed, courses are being continuously expanded and reconsidered - all this in the service of a better comparative law."

Tort law is another area where there has been optimism. By the late 1990s

116 John Hagan, The New Legal Scholarship: Problems and Prospects, 1 CAN. J. L. \& Soc. 35, 35, 37 (1986).

117 John H. Langbein, Scholarly and Professional Objectives in Legal Education: American Trends and English Comparisons in WHAT (Birks), supra note xx, 1, at 6. See also David E. Van Zandt, American Jurisprudence, 1870-1970: a History, by James E. Herget (Book Review), 28 Hous. L. REV. 965, 965 (1991) (“American legal scholarship is vibrant").

118 K.D. Kerameus, Comparative Law and Comparative Lawyers: Opening Remarks, 75 TUL. L. REV. 865, 870 (2001). 
"leading torts scholars (were) looking back with a sense of accomplishment on a generation 'marked by a variety of highly ambitious scholarly developments', namely the increasingly sophisticated economic and corrective justice theories that comprise modern tort theory". ${ }^{119}$

Shifting from individual subject areas to particular approaches that can be adopted to study law, optimists can again be found. It has been said, for instance, that “(w)ithin the legal academy, the achievements of feminism have been substantial and cumulative". ${ }^{120}$ Moreover, Richard Epstein, a leading law and economics scholar, has expressed concerns about the future of the discipline but still argues that for a number of decades "the rate of intellectual return on relatively straightforward problems was exceedingly high." ${ }^{\prime 21}$ The upshot is that there appears to be more to legal scholarship than the plot in the movie "Groundhog Day", in which Bill Murray was condemned to wake up each day and find that it was yesterday all over again.

E. Academic Fads and Fashions

In the foregoing section, a characteristic uniting the academics who were cited to cast doubt on the cyclical account of legal scholarship was that they were offering an appraisal of the field that implied things were getting "better". Still, even if legal

119 Virginia Nolan and Edmund Ursin, The Deacademification of Tort Theory, 48 U. KAN. L. REV. 59, 59 (1999) (quoting an American Association of Law Schools pamphlet but arguing that the sense of accomplishment is misplaced).

$120 \quad$ Ngaire Naffine, In Praise of Legal Feminism, 22 LEGAL STUD. 71, 71 (2002).

121 Richard A. Epstein, Law and Economics: Its Glorious Past and Cloudy Future, 64 U. CHI. L. REV. 1167, 1172 (1997). For a similar verdict, see Thomas S. Ulen, Firmly Grounded: Economics in the Future of Law, [1997] WISCONSIN L. REV. 433, 434, 463. 
scholarship does not evolve simply by reference to the past, does this mean that "progress" is inevitable? Work done by law professor Cass Sunstein on fads, fashions and academic "cascades" indicates the answer is no.

Sunstein subscribes to the notion that there is a market for legal scholarship with academics constituting the producers and consumers including other academics, students, government officials and judges. ${ }^{122}$ He doubts, however, whether the forces of supply and demand yield beneficial outcomes in this context. ${ }^{123}$ Skepticism about the market for legal scholarship is, as we have seen, not novel. ${ }^{124}$ Sunstein does more, however, than suggest there is a case of market failure. Instead, he draws upon social science literature on fads and fashions to suggest how academic writing about law might evolve.

To understand the argument Sunstein is making, some background is required. Typically, when economists model markets they assume that parties have full information about all relevant circumstances. In the real world, however, people are not in this position. A way they can compensate is to learn by observing the actions of others. Correspondingly, when members of a group are cognizant of each other's behavior, they can often end up making the same choices. This sort of "herd behavior" can create a "cascade" that yields a "fad". ${ }^{125}$ The decisions of an individual

\footnotetext{
122 Sunstein, Forewordsupra note xx, at 1253.

$123 \quad I d$. at $1251-52,1264$.

$124 \quad$ Supra note $\mathrm{xx}$ to $\mathrm{xx}$ and related discussion.

125 On cascades and related behavior, see Sushil Bikhchandani et al, Learning from the Behavior of Others: Conformity, Fads, and Informational Cascades, $12 \mathrm{~J}$. ECON. PERSP. 151 (1998); David Hirshleifer, Informational Cascades and Social
} 
with a reputation for being well-informed - a "fashion leader" - can exaggerate the behavior in question. ${ }^{126}$

An important aspect of cascades is that, because they are based on weak information, the conformist behavior involved can occur when the initial choice was poor. Admittedly, if there is a cascade based around an erroneous premise, the dissemination of pertinent and persuasive conflicting information can operate as a corrective. ${ }^{127}$ Still, the relevant facts may never become fully available so a reversal cannot be taken for granted.

Sunstein has extended the learning on cascades, fads and so on to the context of legal scholarship. ${ }^{128} \mathrm{He}$ argues that academic lawyers typically lack reliable information about what is "true" or "right". ${ }^{129}$ As a result, the signals that provide the foundation for fads can be influential within the legal academy. ${ }^{130} \mathrm{He}$ argues that the effect is reinforced because legal academics are concerned about their reputations and thus are cautious about defying a consensus adopted by respected peers. ${ }^{131}$ Also

Conventions in 2 The New PALGRAVE Dictionary of ECONOMICS AND THE LAW 300 (Peter Newman ed., 1998); Robert J. ShILlER, IrRATIONAL EXUbERANCE (2000), chapter 8 .

126 Bikhchandani et al, Learning, supra note $\mathrm{xx}$, at 160; Hirshleifer, supra note $\mathrm{xx}$, at 302.

127 Hirshleifer, supra note $\mathrm{xx}$, at 301, 303.

128 Academia had previously been identified as an environment where the literature seemed relevant: Hirshleifer, supra note $\mathrm{xx}$, at 305.

129 Sunstein, supra note $\mathrm{xx}$, at 1254.

$130 \quad$ Id. at $1254-56$

131 Id. at 1256-58. This is known as a "reputational cascade". See Robert C. Ellickson, The Market for Social Norms, 3 AM. L. \& ECON. REV. 1, 26 (2001). 
significant is that a new line of thinking can coalesce around views adopted by a likeminded group which moves collectively via mutual self-reinforcement towards an extreme position ("group polarization”). ${ }^{132}$ This process can, in turn, provide an ideal platform for "fashion leaders" to act as "polarization entrepreneurs" who amplify informational signals via the medium of a supportive network of followers. ${ }^{133}$

Sunstein admits that some fads "burn out" quickly because, once the relevant points have been raised, little can be done with them. ${ }^{134}$ Others, he says, can be displaced by external shocks, such as changes in the political climate or major innovations in related fields. ${ }^{135}$ What about fads that endure? Does longevity mean that the relevant ideas are "good" or "true"? According to Sunstein, no. He acknowledges that cogent arguments and contradictory evidence can puncture a misguided set of claims. Still, so long as faulty informational signals, reputational concerns and "group polarization" continue to fortify a particular fad, bad ideas can enjoy considerable longevity. ${ }^{136}$

Sunstein, by applying the literature on cascades to legal scholarship, has articulated in a systematic fashion sentiments expressed by some others. Roger

Younger scholars do have an incentive to discover novel approaches, but arguably the legal academy's reward structure requires that their elders can appreciate the innovative move as continuing a tradition with which the elders are associated. See Tushnet, Everything Old, supra note xx, at 581.

132 Sunstein, supra note $\mathrm{xx}$, at 1258-60.

133 Id. at $1260-61$.

$134 \quad I d$. at 1263.

135 Id. at 1261-62.

136 Id. at 1263-64. 
Cramton, an American legal academic, has suggested that "(s)cholarship, perhaps more than other facets of legal culture, is responsive to fashions". ${ }^{137}$ William Twining, an English legal scholar, has observed that
"it is not unknown within jurisprudence for a book-of-the moment, a robust debate, or some dramatic event to attract the ad hoc attention of swarms of jurists like moths to a flame."138

Duxbury has said more generally that American legal scholarship is "characterized increasingly by faddishness" and has argued that "American legal theorists are nothing if not slaves to fashion". ${ }^{139}$

For the sake of argument, let us assume fads do influence legal scholarship. Does this mean that Sunstein's premise that mistaken ideas can easily become both influential and durable must be accepted as well? The answer is no. Certainly Twining does not accept that fads necessarily yield deleterious consequences. Instead, he says that "(i)f fashion...or intellectual snobbery have produced some imbalances or distortions within legal theory, these are faults which are quite easily corrected."140 Twining does not elaborate on how precisely this might occur. Presumably, though, he was assuming that fads are fragile since subsequent intellectual discourse will reveal the faulty nature of the ideas initially advanced.

\footnotetext{
137 Cramton, Demystifying, supra note xx, at 14.

138 William Twining, Academic Law and Legal Philosophy: The Significance of Herbert Hart, 95 LAW Q. REV. 557, 569 (1979).

139 Neil Duxbury, History as Hyperbole, 15 OXF. J. LEGAL STUD. 477, 487 (1995).
} 
Twining, then, is a "cascade optimist" who has faith in the presence of corrective forces that will spring into action when things have gone badly off the track.

Sunstein, on the other hand, seems to be a "cascade pessimist" who doubts whether faulty academic fads will be shattered by the dissemination of new information. ${ }^{141}$

Offering a definitive assessment of the durability of faulty intellectual cascades is not possible at this juncture since even Sunstein has acknowledged that his "informal and anecdotal" analysis is only intended to operate as a platform for further discussion. ${ }^{142}$ Nevertheless, it is possible to identify a factor which could be relevant, this being the extent to which legal scholarship circulates in a "closed" or "open" network. ${ }^{143}$ Again, an intellectual bandwagon built upon the "wrong" outcome will tend to be fragile since the release of new data or ideas can expose the erroneous underpinning of the fad. ${ }^{144}$ Correspondingly, a misguided legal scholarship cascade should be more vulnerable when there is a broadly-based audience with a wide range of expertise than when the relevant field is a small, specialized and insulated.

The network in which legal scholarship circulates can open in various directions. There can, for instance, be exchanges between those specializing in different areas of the law or dialogue between legal scholars and academics working

140 Twining, Academic, supra note xx, at 570.

141 The optimism/pessimism terminology is borrowed from Ellickson, Market, supra note $\mathrm{xx}, 35$ (discussing "norm optimists" and "norm pessimists").

142 Sunstein, Forewordsupra note xx, at 1252-53.

143 On the effect which open vs. closed networks can have on the quality of legal scholarship, see Posner, Legal Scholarship, supra note xx, at 1325.

$144 \quad$ Supra note $\mathrm{xx}$ and related discussion. 
in other disciplines which offer insights directly pertinent to the analysis of legal topics. With respect to correcting misguided fads, however, perhaps the most promising possibility is interchange between law professors and those who work with the law in a practical setting (e.g. lawyers, judges and government officials dealing with legal issues).

Consider, for instance, the analysis of the international law field offered by David Kennedy in a 2000 article. ${ }^{145}$ Applying the terminology used here, he qualifies as a "cascade optimist". This is because he says that ideas in international law which are useful will be picked up and may contribute to a new disciplinary consensus and those which are not will be left to one side. ${ }^{146}$ He says the primary reason for this outcome is that legal practitioners who deal with international law issues assess the persuasiveness and ultimate value of academic work. He describes the discipline they exercise as follows:

“(W)hen practitioner-beings assess things, they do so with their eyes wide open, unaffected by the fashions and egos that befuddle scholars. Their focus is relentlessly on the real world where the rubber meets the road, and it is their judgment, or predictions about their judgment, that guarantees the pragmatism and political neutrality of the field's development." 147

Richard Posner has made related suggestions with respect to interdisciplinary legal scholarship dealing with moral philosophy and bankruptcy law. He argues that
145
Kennedy, supra note xx.
146
Id. at 398 . 
with legally-oriented debates on moral philosophy "quality control" is likely to be a serious problem. This is because "a law professor's article on Hegelian jurisprudence" might only be read by "other law professors interested in Continental philosophy" with "no leakage outside that narrow network". ${ }^{48}$

Posner is more optimistic about bankruptcy law, where the mathematically oriented analysis of choice known as game theory has strongly influenced leading interdisciplinary scholars in the field. ${ }^{149} \mathrm{He}$ acknowledges that a practicing lawyer would not consult articles on bankruptcy law that apply such an exotic approach. On the other hand, "treatise writers and other bankruptcy scholars read (this literature) and (incorporate) their insights into their own, practitioner-friendly works...."150 The result is that, as with international law, "practitioner beings" ultimately are part of the feedback loop. Correspondingly, to the extent that open vs. closed networks do indeed affect the durability of misguided academic fads, a mistaken cascade should be more durable in the area of moral philosophy than with bankruptcy law.

The notion that a misguided legal scholarship fad will be more vulnerable if there is an active dialogue between academics and practitioners is consistent with a broader thesis, namely that the quality of academic writing on law will be better if law Id. at 399.

148 Posner, Legal Scholarship, supra note xx, at 1325-26.

149 For examples, see THOMAS H. JACKSON, THE LOGIC AND LiMITS OF BANKRUPTCY LAW 11-16, 29-31, 57-63 (1986); Alan Schwartz, Bankruptcy Workouts and Debt Contracts, 36 J.L. \& ECON. 595 (1992). 
professors seek consciously to relate their work to the "real world". ${ }^{151}$ The belief on this count is that "( $p)$ ure scholars may be more inclined to espouse views that are fanciful, extreme, or otherwise ungrounded in reality". ${ }^{152}$ The proposition, however, that the quality of legal scholarship is "better" when academic writing has a strong practical dimension does not command universal acceptance. One counter-argument is that legal academics with well-developed professional connections will be influenced by client preferences, rather than saying what they think "without fear or favor". ${ }^{153}$ Another is that a law professor with tight links to the legal profession will have neither the time nor the inclination to undertake the sort of writing that challenges the premises underlying traditional legal analysis. ${ }^{154}$ Ultimately, then, even if academic fads are less likely to endure in fields where academics engage in ongoing dialogue with practitioners, it cannot be taken for granted that the quality of scholarship will be higher.

F. Conclusion

$151 \quad$ Rakoff, Introduction, supra note $\mathrm{xx}$, at 1286-87; Judith S. Kaye, One Judge's View of Academic Law Review Writing, 39 J. LEGAL EDUC. 313, 318-21 (1989); Jean R. Sternlight, Symbiotic Legal Theory and Legal Practice: Advocating a Common Sense Jurisprudence of Law and Practical Applications, 50 U. MiAMI L. REV. 707, $772-75$ (1996). Cf. Tamar Frankel, Of Theory and Practice, 77 CHI.-KENT L. REV. 5, 14-16, 24-28 (2001) (arguing that it will be beneficial for theorists to think in practical terms but stressing that successful implementation cannot be taken for granted because theorists inevitably will have different goals than practitioners).

152 Brown, Should Law, supra note xx, at 334.

153 Eisenberg, Scholar, supra note xx, at 393.

154 Ackerman, Marketplace, supra note xx, at 1135-37; Meir Dan-Cohen, Listeners and Eavesdroppers: Substantive Legal Theory and its Audience, $63 \mathrm{U}$. CoLO. L. REV. 569, 586-88 (1992). 
We have now considered a series of potential trajectories for legal scholarship. Each has a certain plausibility. The idea that our knowledge of the legal system can accumulate by the proper application of scientific method has had enduring appeal. On numerous occasions, intellectual trends relating to law have been described in Kuhnian terms. It is possible to draw analogies from the conventional economic analysis of markets to offer an optimistic prognosis for legal scholarship. There have been pendulum swings in the academic literature on law, which implies that there may be "nothing new under the sun". Finally, the fact that legal academics cannot possibly be fully aware of what might be "right" or "true" means that the field is susceptible to fads.

At the same time, no single account of the manner in which legal scholarship evolves is fully convincing. To illustrate, the fact that much academic writing about law is akin to advocacy means it is inappropriate to equate legal scholarship fully with either the received wisdom concerning natural sciences or Kuhn's recharacterization of scientific endeavor. Moreover, while it may be accurate to say that there is a market for legal scholarship, the manner in which the forces of supply and demand operate diverges considerably from the pattern with more conventional products or services. At the same time, there is sufficient evidence that academic writing on law has become "better" over time to suggest that the pessimism implied by a cyclical account or Sunstein's fad-driven thesis is not fully justified.

A related point is that the various trajectories that have been identified are, at least in some measure, contradictory. For instance, since Kuhn's work was intended to cast doubt on the received wisdom on the accumulation of knowledge in the natural 
sciences, legal scholarship seemingly cannot conform both to a Kuhnian framework and a scientifically-oriented cumulative model. Also, if legal scholarship consists primarily of a "pendulum swing" conversation about enduring issues, it becomes difficult to envisage how there could be "progress" of any meaningful sort. Moreover, Sunstein's account of fads constitutes an explicit challenge to those who believe a marketplace of ideas yields better academic writing about law.

Is it possible to disentangle these various accounts of legal scholarship? Is one trajectory truly predominant? If not, do the dynamics involved necessarily conflict? Or is it possible for various trajectories to influence the evolution of legal scholarship simultaneously? Part III of the paper considers these and related questions by way of a case study, with the focus being on corporate law scholarship. A brief historicallyoriented summary of the literature will begin the discussion. An international perspective will then be offered. The remainder of part III will consider the extent to which corporate law scholarship has evolved in accordance with the various trajectories outlined thus far.

\section{CORPORATE LAW}

A. Corporate Law Scholarship: A Historical Sketch

1. Corporate Personality

During the $19^{\text {th }}$ century, legislatures in the United States, Britain and other jurisdictions began to enact "modern" corporate laws that established straightforward 
procedures for incorporating business enterprises. ${ }^{155}$ The first major theoretical debate to follow this development concerned corporate "personality". As legal historian Morton Horwitz has observed, “(b)eginning in the 1890s and reaching a high point around 1920, (this was) a virtual obsession in the legal literature". 156

Three camps of opinion could be discerned. ${ }^{157}$ First, the "fiction" or "artificial entity" theory held that corporate organizations were mere abstractions that owed their existence and legitimacy to an official grant of authority (a "concession") from the state. ${ }^{158}$ Second, the contractual/association theory implied that a corporation was not a product of sovereign intervention but instead was an association constituted by the aggregation of freely contracting individuals, namely the shareholders. ${ }^{159}$ Third, the "real entity" theory held that a corporation was not fictional but instead had a distinctive personality in the same sense that a human being does. This implied, in turn, that a corporate entity must be conceptually separate and distinct from those owning the equity. ${ }^{160}$

155 PAUl L. DAVIES, GOWER's PRINCIPLES OF MODERN COMPANY LAW 36-46 $\left(6^{\text {th }}\right.$ ed. 1997); F.W. WEGENAST, THE LAW OF CANADIAN COMPANIES 17-27 (1931).

156 HoRwITZ, supra note $\mathrm{xx}, 101$.

157 Id. at 75; Mark M. Hager, Bodies Politic: The Progressive History of Organizational “Real Entity” Theory, 50 U. PITT. L. REV. 575, 579-80 (1989).

158 William W. Bratton, The New Economic Theory of the Firm: Critical Perspectives from History, 41 STAN. L. REV. 1471, 1502-8 (1989).

159 Id. at $1489-90$.

160 Gregory A. Mark, The Personification of the Business Corporation in American Law, 54 U. CHI. L. REV. 1441, 1468-77 (1987); Dalia Tsuk, Corporations Without Labor: The Politics of Progressive Corporate Law, 151 U. PA. L. REV. 1861, 1871-72 (2003). 
The dialogue concerning corporate personality was, for its time, strikingly theoretical in tone and was much more international in orientation than was traditional with legal discourse. ${ }^{161}$ Still, by 1930 the debate had largely ended. ${ }^{162}$ By this time, the consensus view was that the corporation was an important legal form that could not be treated, from the law's point of view, as a mere contractual aggregation. Also, though corporate personality had to be taken seriously from a legal perspective, corporate entities could not be analyzed as actual persons. John Dewey, with an article published in 1926, did much to take the wind out of the corporate personality debate by saying it was misconceived because of a preoccupation with abstract concepts rather than concrete things. ${ }^{163}$

\section{Berle and Means}

As the personification of the corporate entity faded as a concern, the stage was set for American legal academics to think about the corporation in functional rather than abstract terms. Adolf Berle and Gardiner Means' The Modern Corporation and Private Property, ${ }^{164}$ originally published in 1932, provided an ideal platform for the

161 Mark, Personification, supra note xx, at 1465-67.

162 Bratton, New, supra note xx, at 1493; BEN PETTET, COMPANY LAW 53 (2001).

163 John Dewey, The Historic Background of Corporate Legal Personality, 35 YALE L.J. 655 (1926). On the impact of this article, see Hager, supra note xx, 63539; William W. Bratton, Berle and Means Reconsidered at the Century's Turn, 26 J. CORP. L. 737, 741-43 (2001).

164 Adolf A. Berle and Gardiner C. Means, The Modern Corporation \& PrIVATE PROPERTY (Murray Weidenbaum and Mark Jensen eds., Transaction Publishers 1991) (1932). 
shift in emphasis. ${ }^{165}$ The authors analyzed the results of a "corporate revolution" that had occurred in the US between 1880 and $1930 .{ }^{166}$ During this period, in many key industries small closely held firms managed by their founders gave way to big publicly traded companies characterized by managerial hierarchies. In these "quasipublic corporations" ${ }^{\$ 67}$ widely dispersed shareholders, each lacking a sufficient financial incentive to intervene directly, left it to professionally trained executives to deal with matters of importance. The result, according to a phrase Berle and Means made famous, was a "separation of ownership and control". ${ }^{168}$

An inference that many American corporate law scholars drew from Berle and Means' separation of ownership and control thesis was that something was seriously amiss in publicly quoted corporations. ${ }^{169}$ More precisely, the "managerialist" pattern Berle and Means had described implied that those in charge of America's larger business enterprises were not sufficiently accountable to shareholders. ${ }^{170}$ As a

165 See Mark, Personification, supra note xx, at 1480-81 as well as HoRwITZ, supra note $\mathrm{xx}$, at 166; Bratton, Berle, supra note $\mathrm{xx}$, at 743, 753-54; Gregory A. Mark, Realms of Choice: Finance Capitalism and Corporate Governance, 95 COLUM. L. REV. 969, 974-75 (1995).

166 On the "corporate revolution" terminology, see Walter Werner, Corporation Law in Search of its Future, 81 CoLUM. L. REV. 1611, 1641-42 (1981); William G. Roy, Socializing CAPITAL: THE RISE OF THE LARGE INDUSTRIAL CORPORATION IN AMERICA 3, 176 (1997).

167 BERLE AND MEANS, supra note xx, at 5.

$168 I d$. at 3.

169 Henry G. Manne, The Myth of Corporate Responsibility or Will the Real Ralph Nader Please Stand Up?, 26 Bus. LAw. 533, 533 (1970).

170 Elliot J. Weiss, Social Regulation of Business Activity: Reforming the Corporate Governance System to Resolve an Institutional Impasse, 28 U.C.L.A. L. REV. 343, 414 (1981); William J. Carney, The Legacy of "The Market for Corporate 
Harvard economist said in 1959, “(a)lmost everyone now agrees that in the large corporation, the owner is, in general a passive recipient; that typically control is in the hands of management; and that management normally selects its own replacements". ${ }^{171}$ The inference many drew was that managers of large corporations were "irresponsible oligarchs". ${ }^{172}$

Academics who were concerned about the uneven balance of power between managers and shareholders advocated various types of reform. These included fostering more participation by investors in corporate affairs (activating "shareholder democracy"), ${ }^{173}$ strengthening the fiduciary duties top executives owe to their companies ${ }^{174}$ and advocating strict monitoring of management by "outside" directors lacking any compromising link with management. ${ }^{175}$ Still, while corporate law academics frequently invoked the separation of ownership and control thesis to advocate stronger shareholder rights, this was not the only argument in favor of regulation that could be derived from The Modern Corporation and Private Property.

Control" and the Origins of the Theory of the Firm, 50 CASE W. RES. L. REV. 215, 221, 223 (1999).

171 Edward S. Mason, Introduction, in THE CORPORATION IN MODERN SOCIETY 1, 4 (Edward S. Mason ed., 1959).

172 Carl Kaysen, The Social Significance of the Modern Corporation, 47 AM. ECON. REV. 311, 316 (1957).

173 Bayless Manning, Thinking Straight About Corporate Law Reform, 41 LAW \& Contemp. Probs. 3, 14 (1977).

$174 \quad$ Weiss, supra note $\mathrm{xx}$, at 414.

175 Melvin A. Eisenberg, Legal Models of Management Structure in the Modern Corporation: Officers, Directors, and Accountants, 63 CAL. L. REV. 375, 407-9 (1975). 
Instead, Berle and Means' "analysis was a gun on a rotating platform that could be pointed in more than one direction."

Most notably, The Modern Corporation and Private Property posed, if indirectly, the question: should the legal system make those managing corporations accountable to society as a whole? The effect was to cast doubt on the received wisdom under U.S. law, which was that the objective of corporations is to generate profits for their shareholders ("shareholder primacy"). ${ }^{177}$ Berle and Means themselves stressed that power was increasingly being concentrated in the hands of large companies. ${ }^{178}$ This in turn implied that the corporation needed to be understood as a social and political institution, not merely an economic entity. ${ }^{179}$ Various U.S. academics, taking their cue from The Modern Corporation and Private Property,

176 J.A.C. Hetherington, Redefining the Task of Corporation Law, 19 U.S.F. L. REV. 229, 235 (1985).

177 Bratton, Berle, supra note $\mathrm{xx}$, at 761-62; Phillip I. Blumberg, The

Politicization of the Corporation, 26 Bus. LAW. 1551, 1556 (1971); SCOTT R. Bowman, The Modern Corporation ANd American Political Thought: Law, POWER, AND IDEOLOGY, 186, 206 (1996). On the law, see Robert C. Clark, Corporate Law 678-79 (1986); Stephen M. Bainbridge, Director Primacy: The Means and Ends of Corporate Governance, 97 Nw. U. L. REV. 547, 600-5 (2003).

178 BERLE AND MEANS, supra note xx, Book I, ch. 3. On the importance of this theme, see Tsuk, supra note $\mathrm{xx}$, at 1885-86.

179 BERLE AND MEANS, supra note xx at 309-13. It is somewhat ironic that Berle and Means' work cast doubt on what was the received wisdom under American law, namely that generating profits for shareholders is the objective corporations should pursue. This is because Berle, in a well-known exchange with E.M. Dodd, expressed doubt whether the law was capable of expanding to accommodate the perceived public responsibilities of the modern corporation. See Adolf A. Berle, For Whom Corporate Managers are Trustees: A Note, 45 HARVARD L. REV. 1365 (1932); Edwin M. Dodd, For Whom are Corporate Managers Trustees?, 45 HARVARD L. REV. 1145 (1932). Berle subsequently conceded that the debate had been settled in favour of Dodd's position: A.A. BERLE, THE 20TH CENTURY CAPITALIST 
cited the growing power of corporations to advocate changing the law to address concerns about corporate social responsibility. ${ }^{180}$

In 1962, one of the authors of The Modern Corporation and Private Property observed that their work had achieved the status of "folklore" within the legal academy. ${ }^{181}$ American law professors concurred. In 1984 Roberta Romano observed that "after half a century, discussion of the corporate form still invariably begins with Berle and Means' location of the separation of ownership and control as the master problem for research". ${ }^{182}$ Henry Manne put the point even more strongly, saying in 1987 that "(n)o field of American law has ever been so totally dominated by one work as the corporation law area by the Berle and Means classic". ${ }^{183}$

\section{Contractarian Analysis}

REVOLUtion 169 (1955). For an overview of the Berle/Dodd dialogue, see Tsuk, supra note $\mathrm{xx}, 1891-96,1899$.

180 See, for example, Weiss, supra note xx, at 344-46, 418-26; Abram Chayes, The Modern Corporation and the Rule of Law in CORPORATION (Mason), supra note xx, 25, 38-45; Thomas J. Schoenbaum, The Relationship Between Corporate Disclosure and Corporate Responsibility, 40 FORDHAM L. REV. 565, 578, 587-94 (1972).

181 Adolf A. Berle, Modern Functions of the Corporate System, 62 CoLUM. L. REV. 433, 433 (1962).

182 Roberta Romano, Metapolitics and Corporate Law Reform, 36 STAN. L. REV. 923, 923 (1984).

183 Henry G. Manne, Intellectual Styles and the Evolution of American Corporate Law, in ECONOMIC IMPERIALISM: THE ECONOMIC APPROACH APPLIED OUTSIDE THE FIELD of ECONOMICS, 219, 223 (Gerard Radnitzky and Peter Bernholz, eds., 1987). For similar observations, see Robert Hessen, A New Concept of Corporations: A Contractual and Private Property Model, 30 Hastings L.J. 1327, 1329 (1979); George W. Dent, Toward Unifying Ownership and Control in the Public Corporation, [1989] WISC. L. REV. 881, 881; Craig LaChance, Nature v. Nurture, Evolution, Path 
While Berle and Means' work strongly influenced U.S. corporate law scholarship, the inferences drawn from it were subjected to increasingly critical scrutiny as the $20^{\text {th }}$ century drew to a close. A pivotal step in this process was the emergence of the economically-oriented "contractarian" model of the corporation. Prior to the 1970 s, economists treated the business enterprise, typically referred to as a firm, as a "black box" that operated so as to maximize profits. ${ }^{184}$ The situation then changed. ${ }^{185}$ Economists began to concern themselves with how the conflicting objectives of individual participants associated with firms might be aligned so as to yield the hypothesized focus on profit maximization. ${ }^{186}$ The prevailing view became that market exchanges did not end at a firm's front door. Instead, the internal organization of business enterprises was the result of voluntary exchanges dictated by market forces. At the same time, market dynamics defined the relationship between a firm and its suppliers, customers, creditors and so on. The firm, in short, was a "nexus of contracts". 187

Dependence and Corporate Governance, 18 ARIZ. J. INT'L \& COMP. L. 279, 282-83 (2001).

184 William W. Bratton, The "Nexus of Contracts" Corporation: A Critical Appraisal, 74 CoRnell L. REV. 407, 415-16 (1989); Paddy Ireland, Defending the Rentier: Corporate Theory and the Reprivatisation of the Public Company, in THE Political ECONOMY OF THE COMPANY 141, 157 (John Parkinson et al.eds., 2000). 185 Bratton, Nexus, supra note xx, at 415; Ireland, Defending, supra note xx, at 157-58.

186 Michael C. Jensen and William H. Meckling, Theory of the Firm: Managerial Behavior, Agency Costs and Ownership Structure, 3 J. FIN. ECON. 305, 307 (1976). Ronald Coase had previously explored the issues involved: Nature of the Firm, 4 ECONOMICA 386 (1937). His work, however, was largely ignored until the 1970s: Bratton, Nexus, supra note xx, at 416; Ireland, Defending, supra note xx, at 157.

187 See Jensen and Meckling, Theory, supra note xx, at 311 ("a nexus for contracting relationships"); Eugene F. Fama, Agency Problems and the Theory of the 
A pivotal aspect of the nexus of contracts model was "agency cost" theory. ${ }^{188}$ Again, the Berle-Means analysis of the widely held company implied that shareholders potentially might be subjected to the untrammeled whims of powerful executives. Agency cost theory provided an analytical framework for examining this divergence of interest. The starting point with the theory was that, whenever one individual ("the principal”) depends upon another ("the agent"), from an economic perspective an agency relationship arises. ${ }^{189}$ Since agents do not receive all of the returns from the profit enhancing activities they engage in on behalf of their principals, they will always be tempted to put their own interests first. When agents in fact do so, the result is "agency costs". In a corporation with widely dispersed share ownership the shareholders, as principals, depend on management, as agents, to operate the business profitably. Self-serving or reckless managerial conduct therefore creates agency costs for investors.

While agency cost theory characterized in a systematic way the sort of incentive problems which Berle and Means had identified, it did more than this. It implied as well that executives in widely held public companies were not as unaccountable as the separation of ownership and control thesis suggested. This is because agency cost theory offered an intellectually elegant account of various

Firm88 J. POL. ECON. 288, 290 (1980). For background, see Margaret M. Blair, and Lynn A. Stout, A Team Production Theory of Corporate Law, 85 VA. L. REV. 247, 319, n. 189 (1999).

188 Jensen and Meckling, Theory, supra note $\mathrm{xx}$ was the seminal contribution to the literature. For a summary of the agency cost concept, see BRIAN R. CHEFFINS, COMPANY LAW: THEORY, STRUCTURE AND OPERATION 45 (1997).

189 The economy theory of agency costs must be distinguished from the legal concept of agency: CHEFFINS, supra note xx, at 45. 
market-oriented limitations on the exercise of managerial discretion. ${ }^{190}$ One such constraint is the labor market for executives (senior managers want to run companies well to impress potential alternative employers). ${ }^{191}$ Another is the market for a company's products or services (executives will lose their jobs if a decline in market share is sufficiently precipitous to cause the company to fail). Also significant is the capital market (companies which want to raise money receive less advantageous terms if there is evidence of mismanagement). The market for corporate control constitutes an additional constraint on managerial misconduct since bidders, intent on generating profits by installing new executives, can make offers to the buy the outstanding equity of poorly run companies.

In addition to providing a platform for re-evaluating the position of management, the nexus of contracts model opened the way for a reconceptualization of the shareholder's status within the corporation. As exemplified by the phrase "separation of ownership and control", shareholders have often been characterized as the "owners" of a company. ${ }^{192}$ Contractarian analysis dispenses with this "tenacious notion"193 and instead treats those who own equity as "residual claimants". ${ }^{194}$ From a

190 Jason Scott Johnston, The Influence of "The Nature of the Firm” on the Theory of Corporate Law, 18 J. CORP. L. 213, 234-35 (1993).

191 On this and other market-oriented constraints managers face, see CHEFFINS, supra note $\mathrm{xx}$, at $117-23$.

192 Lynne L. Dallas, Working Toward a New Paradigm, in PROGRESSIVE Corporate LAw 35, 37 (Lawrence E. Mitchell, ed., 1995); Ross Grantham, The Doctrinal Basis of the Rights of Company Shareholders, 57 CAMBRIDGE L.J. 554, 554-55 (1998); Paddy Ireland, Company Law and the Myth of Shareholder Ownership, 62 MoD. L. REV. 32, 32, 48-49 (1999).

193 Fama, supra note xx, at 290; see also Daniel R. Fischel, The "Race to the Bottom" Revisited: Reflections on Recent Developments in Delaware's Corporation 
contractual perspective, shareholders are defined in this way because they are the ultimate beneficiaries of whatever success a company enjoys, in the sense that the return on their investment is based on what is left over after other claims the company is obliged to meet have been satisfied. ${ }^{195}$ Hence, while others who are part of a corporate nexus of contracts will contract to receive fixed cash sums (e.g. creditors and employees), the return a company's equity yields is variable in nature and is a function of the net cash flow the business generates over time. ${ }^{196}$

If shareholders in a company merely constitute one constituency that is part of a nexus of contracts, one could infer that the "shareholder primacy" principle that has influenced U.S. corporate law is misguided. ${ }^{197}$ "Contractarians", however, did not embrace such logic and instead sought to justify the pre-eminent position of shareholders. They defended shareholder primacy on the grounds that equity

Law, 76 Nw. U. L. REV. 913, 917-18 (1982); Stephen M. Bainbridge, In Defense of the Shareholder Wealth Maximization Norm: A Reply to Professor Green, 50 WASH. \& LEE L. REV. 1423, 1428 (1993).

194 Ireland, Defending, supra note xx, at 164-66 (summarizing the literature).

195 CHEFFINS, supra note xx, 54; William A. Klein, The Modern Business Organization: Bargaining Under Constraints, 91 YALE L.J. 1521, 1538-40 (1982); Henry N. Butler, The Contractual Theory of the Corporation, 11 GEO. MASON L. REV. 99, 107 (1989). For criticism of this reasoning, see Lynn A. Stout, Bad and Notso-Bad Arguments for Shareholder Primacy, 75 S. CAL. L. REV. 1189, 1193-95 (2002).

196 ChEFFINS, supra note xx, at 54, 71, 87; Klein, Modern, supra note xx, at 1538; Frank H. EASTERbroOK, AND DANiEl R. Fischel, The ECONOMIC STRUCTURE OF CORPORATE LAW 67-68 (1991).

197 Frank H. Easterbrook, and Daniel R. Fischel, Voting in Corporate Law, 26 J. L. \& ECON. 395, 403, 406 (1983); Melvin A. Eisenberg, The Conception That the Corporation is a Nexus of Contracts, and the Dual Nature of the Firm, 24 J. CORP. L. 819, 833-34 (1999); Thomas A. Smith, The Efficient Norm for Corporate Law: A Neotraditional Interpretation of Fiduciary Duty, 98 MicH. L. REV. 214, 215-17 (1999). 
investors, as residual claimants, have strong incentives to encourage maximum corporate achievement in a manner that benefits their fixed claim counterparts. ${ }^{198}$ Advocates of the nexus of contracts model also cited the respective bargaining positions of shareholders and non-shareholder constituencies to make their case. The point made was that creditors, employees and customers can feasibly bargain for protection whereas shareholders cannot because of the open-ended nature of an investment in corporate equity. ${ }^{199}$

When the nexus of contracts model first arrived on the scene, various legal academics argued forcefully that it was inappropriate to conceptualize the corporation as a nexus of contracts. ${ }^{200}$ Nevertheless, the analytical framework ultimately proved to be highly influential, at least in the American context. In fact, "(l)aw and economics...swept the academic corporate law area like prairie fire", ${ }^{201}$ so that by early 1990s "the dominance of the nexus of contracts model in the legal academy"

198 EASTERBROOK AND FiSCHEL, supra note xx, at 38, 68; Mark E. Van der Weide, Against Fiduciary Duties to Corporate Stakeholders, 21 DEL. J. CoRP. L. 27, 57-66 (1996); Michael Bradley, et al., The Purposes and Accountability of the Corporation in Contemporary Society: Corporate Governance at Crossroads, 62 LAW \& CONTEMP. PROBS. 9, 37-38 (1999).

199 Van der Weide, supra note xx, at 35-55; Jonathan R. Macey and Geoffrey P. Miller, Corporate Stakeholders: A Contractual Perspective, 43 U. TORONTO L.J. 401, 416-19 (1993); Roberta Romano, Corporate Law and Corporate Governance, 5 INDUS. \& CORP. CHANGE 277, 279-80 (1996).

200 See, for example, Bratton, Nexus, supra note xx, Victor Brudney, Corporate Governance, Agency Costs and the Rhetoric of Contract, 85 Colum. L. REV. 1403 (1985); Melvin A. Eisenberg, The Structure of Corporation Law, 89 COLUM. L. REV. 1461, 1485-88 (1989).

201 Douglas M. Branson, A Corporate Paleontologist's Look at Law and Economics in the Seventh Circuit, 65 CHICAGO-KENT L. REV. 745, 745 (1989). 
was becoming widely recognized. ${ }^{202}$ By the end of the decade matters had progressed to the point where the proposition "(t)hat a firm (such as a corporation) can be thought of as a 'nexus of contracts'...ha(d) becom(e) something of a cliché in the university". ${ }^{203}$ Indeed, there currently are those who believe that "(e)very book and journal article in the corporate law field ha(s) to take an economics of law perspective if they (are) to succeed in the marketplace of ideas."204

4. The Nexus of Contracts Model as a Point of Departure

While contractarian analysis is currently the dominant school of thought among academic corporate lawyers in the U.S., its influence is in fact not monolithic. Instead, there a significant number of American corporate law academics who have serious misgivings about the nexus of contracts model. ${ }^{205}$ Those who have their doubts typically do not reject the economic approach in its entirety. Instead, they tend

202 William T. Allen, Contracts and Communities in Corporation Law, 50 WASH. \& LEE L. REV. 1395, 1401 (1993). See also Johnston, Influence, supra note xx, at 213, 231; Lewis A. Kornhauser, The Nexus of Contracts Approach to Corporations: A Comment on Easterbrook and Fischel, 89 COLUM. L. REV. 1449, 1449 (1989); William W. Bratton, The Economic Structure of the Post-Contractual Corporation, 87 Nw. U. L. REV. 180, 180, 190 (1992).

203 J. Mark Ramseyer, Corporate Law in 1 New PALGRAVE, supra note xx, 503, 504 (1998).

204 Douglas M. Branson, Corporate Governance "Reform" and the New Corporate Social Responsibility, 62 U. PITT. L. REV. 605, 619 (2001).

205 Allen, Contracts, supra note xx, at 1399 (saying that some of corporate law's "most respected minds remain among the unconverted"); G. Mitu Gulati et al., Connected Contracts, 47 U.C.L.A. L. REv. 887, 947 (2000). See, for example, Rutherford B. Campbell, Corporate Fiduciary Principles for the Post-Contractarian Era23 Fla. ST. U. L. REV. 561 (1996); Melvin A. Eisenberg, The Conception That the Corporation is a Nexus of Contracts, and the Dual Nature of the Firm, $24 \mathrm{~J}$. CORP. L. 819 (1999). 
to accept the nexus of contracts as a pivotal analytical construct and use it as a point of departure so as to develop a more fully rounded conception of corporate law. ${ }^{206}$

One move made by those who are uneasy with the nexus of contracts model has been to invoke the concept of social norms. The core belief is that the corporation is a prime domain of informal rules of conduct that do as much or more than enforceable legal obligations to shape and determine corporate behavior. ${ }^{207}$ The nexus of contracts model allegedly is not capable of making suitable allowances for this pattern since it tends to assume away gaps in contractual documentation governing relations between those associated with companies. ${ }^{208}$ Correspondingly, proponents of norms-oriented analysis say their approach offers a richer understanding of the interface between law and corporate activity than a standard economic framework. ${ }^{209}$

A potential limitation with a norms-oriented approach to corporate law is that it may end up constituting a useful but limited adjunct to contractarian thinking rather

206 See, for instance, Campbell, Corporate, supra note xx, 576-77; Eric W. Orts, Shirking and Sharking: A Legal Theory of the Firm, 16 YALE L. \& POL'Y REV. 265, 266-67, 298-99 (1998); Margaret M. Blair, and Lynn A. Stout, Trust, Trustworthiness, and the Behavioral Foundations of Corporate Law, 149 U. PA. L. REV. 1735, 173738 (2001); Therese H. Maynard, Law Matters. Lawyers Matter, 76 TUL. L. REV. 1501, 1507, 1528 (2002).

207 John C. Coffee, Do Norms Matter? A Cross-Country Evaluation, 149 U. PA. L. REV. 2151, 2151 (2001); Melvin A. Eisenberg, Corporate Law and Social Norms, 99 COLUM. L. REV. 1253, 1253-54, 1291 (1999).

208 Edward B. Rock, and Michael L. Wachter, Islands of Conscious Power: Law, Norms and the Self-Governing Corporation, 149 U. PA. L. REV. 1619, 1629-30, 163839 (2001).

209 Id. at 1621-23. Rock and Wachter prefer, however, to refer to "nonlegally enforceable rules and standards" or "NLERS" rather than norms: id. at 1641. 
than becoming a self-sufficient and robust analytical framework. ${ }^{210}$ Still, work done on the extralegal norm or practice of "trust" does offer an affirmative model that is intended to account in a systematic fashion for key aspects of corporate activity. More particularly, Margaret Blair and Lynn Stout have used trust as a departure point in asserting that the corporation is best understood as a team of people who enter into a complex agreement to work together for mutual gain. ${ }^{211}$ These academics argue that, with a company, individuals typically devote themselves to the firm in the hopes of sharing the benefits flowing from "team production". Those who do so tend not to seek full contractual protection for the "firm-specific" investments being incurred. ${ }^{212}$ Instead, according to Blair and Stout, they trust the board of directors to balance the interests of the constituencies associated with the corporation in an unbiased manner. The upshot is that the board is supposed to function as a "mediating hierarchy". ${ }^{213}$

Blair and Stout say that the board of directors cannot provide a suitable rallying point for team production if it is simply a proxy for shareholder interests. Instead, they argue, the board must be an unbiased broker amongst a corporation's

$210 \quad C f$. Marcel Kahan, The Limited Significance of Norms for Corporate Governance, 149 U. PA. L. REV. 1869, 1870, 1900 (2001).

211 On the wording, see Blair and Stout, Team, supranote xx, at 278. They have developed their ideas further in Blair and Stout, Trust; supra note xx; Margaret M. Blair and Lynn A. Stout, Director Accountability and the Mediating Role of the Corporate Board, 79 WASH. U.L.Q. 403 (2001). For related work on trust, see Lawrence E. Mitchell, Trust and Team Production in Post-Capitalist Society, $24 \mathrm{~J}$. CORP. L. 869 (1999).

212 Blair and Stout, Team, supra note xx, at 271-72, 275-76; Blair and Stout, Trust, supra note xx, at 1755; Blair and Stout, Director, supra note xx, at 411-21.

213 Blair and Stout, Team, supra note xx, at 276-85; Blair and Stout, Director, supra note $\mathrm{xx}$, at 421-22. 
various constituencies. ${ }^{214}$ Correspondingly, Blair and Stout's work constitutes an economically-oriented challenge to the "shareholder primacy" notion many contractarians advocate. ${ }^{215}$ The pair concedes that giving the board the discretion required to act as a neutral arbiter can give rise to agency problems since individual directors may have little or no financial stake in the firm. ${ }^{216}$ Nevertheless, with cultural norms of fairness and trust encouraging directors to serve the team in a faithful and "other-regarding" fashion, the benefits arising from the proper coordination of team production allegedly exceed the costs. ${ }^{217}$

Blair and Stout defend their argument that boards will function in an "otherregarding" manner by referring to experimentally oriented "behavioral economics" research. ${ }^{218}$ A pivotal lesson this literature offers is that, in particular test environments, people sacrifice their economic self-interest in order to be, or to appear,

214 Blair and Stout, Team, supra note xx, at 253, 286, 298-305; Blair and Stout, Director, supra note $\mathrm{xx}$, at 424-25.

215 David Millon, New Game Plan or Business as Usual? A Critique of the Team Production Model of Corporate Law, 86 VA. L. REV. 1001, 1005-9, 1023-24 (2000).

216 Blair and Stout, Team, supra note $\mathrm{xx}$, at 283; Blair and Sout, Trust, supra note $\mathrm{xx}$, at 1756-57.

217 Blair and Stout, Team, supra note xx, at 283-84, 316; Blair and Stout, Director, supra note $\mathrm{xx}$, at 436-43.

218 Blair and Stout, Director, supra note xx, at 439-40; Blair and Stout, Trust, supra note $\mathrm{xx}$, at 1741, 1766-74. Blair and Stout do not specifically mention "behavioral economics". They rely sufficiently on the relevant literature, however, to be cited as authors who do so. See, for example, Kent Greenfield, Using Behavioral Economics to Show the Power and Efficiency of Corporate Law as a Regulatory Tool, 35 U.C. DAVIS L. REV. 581, 585, n. 9 (2002). 
"fair". ${ }^{219}$ The experimental data currently available is compelling enough to justify corporate law scholars paying attention to potential cognitive biases that are inconsistent with mainstream economic thinking. ${ }^{220}$ Still, it remains unclear at present whether in real-world corporate settings the biases revealed in the behavioral economics literature operate to a significant degree. ${ }^{221}$ Hence, it is an open question whether corporate boards are likely to act as the neutral brokers hypothesized by Blair and Stout.

The team production model does not stand alone as an attempt to use contractarian analysis as a jumping off point to develop a more nuanced conception of the corporation. Law professors Henry Hansmann and Reinier Kraakman have also taken steps in this direction by emphasizing the proprietary aspect of business firms. ${ }^{222}$ They explicitly acknowledge that a firm constitutes a nexus of contracts but note that business is most often conducted through the medium of legal entities rather than simply via "contractual cascades". ${ }^{223}$ Hansmann and Kraakman explain this on

\section{Cass R. Sunstein, Introduction in BEHAVIORAL LAW AND ECONOMICS 1, 8}

(Cass R. Sunstein, ed., 2000).

220 Jennifer Arlen et al., Endowment Effects Within Corporate Agency

Relationships, 31 J. LEGAL ST. 1, 2-4 (2002); for examples of corporate law scholarship where inferences have been drawn from behavioral economics, see Greenfield, Using, supra note xx, at 585, n. 9.

221 Arlen et al., Endowment, supra note xx, at 5-6, 33.

222 Henry Hansmann, and Reinier Kraakman, The Essential Role of Organizational Law, 110 YALE L.J. 387 (2000); Henry Hansmann and Reinier Kraakman, Organizational Law as Asset Partitioning, 44 EUR. ECON. REV. 807 (2000). See also John Armour and Michael J. Whincop, An Economic Analysis of Shared Property in Partnership and Close Corporations Law, 26 J. CORP. L. 983 (2001).

223 Hansmann and Kraakman, Essential, supra note xx, at 391. 
the basis that organizational law permits the formation of a firm that can have ownership of assets of its own.

Corporate law, which is a key subset of organizational law, operates in two important ways with respect to the ownership of assets. First, according to Hansmann and Kraakman's analysis, incorporation permits "affirmative" asset partitioning, which involves assigning to a company's creditors a claim on corporate property that has priority over any rights of the personal creditors of the shareholders. ${ }^{224}$ Also, corporate law facilitates "defensive" asset partitioning, which encompasses shielding the assets of a corporation's shareholders from corporate creditors via limited liability. ${ }^{225}$ Hansmann and Kraakman acknowledge, consistent with analysis offered from a contractarian perspective, that defensive asset partitioning could be achieved by contract. $^{226}$ They assert, however, that it is effectively impossible to create affirmative asset partitioning using basic tools of property, contract and agency law, thus making corporate law "essential". 227

\section{B. The International Dimension}

Implicitly, the foregoing account of the evolution of corporate law scholarship has had an American orientation. The reason is simple. While the debate about

\footnotetext{
$224 \quad$ Id. at 393-95.

$225 \quad I d$.

$226 I d$. at 428-32; see also CHEFFINS, supra note $\mathrm{xx}$, at 39-40. It is not clear whether contractual efforts to create limited liability could be effective with tort claims. Compare Armour and Whincop, supra note xx, at 995 and Paul G. Mahoney, Contract or Concession? An Essay on the History of Corporate Law, 34 GA. L. REV. 873, 885-86 (2000).
} 
corporate personality that took place at the beginning of the $20^{\text {th }}$ century had a distinct international dimension, ${ }^{228}$ subsequently Americans have set the tone with theoretical work on corporate law. ${ }^{229}$ What, then, has been the position with corporate law scholarship elsewhere? The general trend has been to avoid analyzing the subject matter in interdisciplinary terms. For instance, in continental Europe, "hermetically sealed doctrinal analysis" has traditionally dominated the corporate law field and continues to do so at present. ${ }^{230}$ The situation was, at least until quite recently, the same in the United Kingdom. The doctrinal orientation of the relevant literature led one critic to say in 1986 :

“(C)ompany lawyers lack an intellectual tradition which places the particular rules and doctrines of their discipline within a broader theoretical framework which gives meaning and coherence to them." 231

Canadian and Australian corporate law scholarship yielded similar harsh verdicts. ${ }^{232}$

227 Hansmann and Kraakman, Essential, supra note xx, at 406-23.

228 Supra note $\mathrm{xx}$ and related discussion.

229 Cheffins, Using, supra note $\mathrm{xx}$, at 209.

230 John W. Cioffi, State of the Art: A Review Essay on "Comparative Corporate Governance: The State of the Art and Emerging Research," 48 AM. J. COMP. L. 501, 509 (2000). See also Nicholas H.D. Foster, Company Law Theory in Comparative Perspective: England and France, 48 AM. J. CoMP. L. 573, 606-8 (2000).

231 Mary Stokes, Company Law and Legal Theory in LEGAL THEORY AND COMMON LAw 155, 155 (William Twining ed., 1986). See also Foster, supra note xx at 586-92; Pippa Rogerson, Book Review, (1994) 53 CAMBRIDGE L.J. 601, 601. There were occasional isolated exceptions to the dominant pattern, such as TOM HADDEN, COMPANY LAW AND CAPITALISM (1972).

232 Kathleen A. Lahey, and Sarah W. Salter, Corporate Law in Legal Theory and Legal Scholarship: From Classicism to Feminism, 23 OsGOOdE HALL L.J. 543, 557- 
The doctrinal orientation that has prevailed outside the United States appears to be eroding. ${ }^{233}$ In continental Europe, those legal academics interested in accountability and decision-making within publicly quoted companies ("corporate governance") are increasingly looking at issues from an interdisciplinary perspective. ${ }^{234}$ In Britain, Australia and Canada matters have evolved further. Theoretical company law scholarship is now quite well-established, with a growing literature emerging in all three countries. ${ }^{235}$

Since the shift towards interdisciplinary analysis has been recent in orientation, the nexus of contracts model that has influenced the American literature so strongly has inevitably had an impact on theoretical research being conducted outside the U.S. ${ }^{236}$ Indeed, observers in Australia, Canada and the U.K. generally

69 (1985); Katherine H. Hall, The Interior Design of Corporate Law: Why Theory is Vital to the Development of Corporate Law in Australia, 6 AUsTL. J. CORP. L. 1, 1, 45 (1996); David Wishart, Does the High Court Understand Corporations Law? 6 AusTL. J. CORP. L. 424, 436-38 (1996) (acknowledging that some theoretical work was being done in Australia but arguing that it was superficial in orientation).

233 This is consistent with general trends. See Van Zandt, supra note xx, at 968 (saying that foreign scholars increasingly want to learn more about American theories and approaches and see their own country's scholarship as too closely tied to practice).

234 Cioffi, supra note $\mathrm{xx}$, at 508-9.

235 Cheffins, Using, supra note $\mathrm{xx}$, at 209; Foster, supra note xx, at 593-94; Byran Horrigan, Teaching and Integrating Recent Developments in Corporate Law, Theory and Practice, 13 AUSTL. J. OF CORP. L. 182, 185-86 (2001). For a more pessimistic appraisal of the situation in Australia, see Frank Carrigan, The Role of Capital in Regulating the Duty of Care and Business Judgment Rule, 14 AUSTL. J. OF CORP. L. 215, 215-16, 237-38 (2002).

236 Cioffi, supra note xx, at 509; Foster, supra note xx, at 593; J. Anthony VanDuzer, Book Review, 77 CAN. BAR REV. 567, 567 (1998); Michael Whincop, of Fault and Default: Contractarianism as a Theory of Anglo-Australian Corporate Law, 21 MeLB. U. L. REV. 187, 188-89 (1997). 
acknowledge that the nexus of contract model has been dominating the theoretical discourse. ${ }^{237}$ Still, while the economic approach to corporate law that has been so influential in the United States has attracted attention elsewhere, its impact has varied. Canadian scholars look regularly to the law and economics literature to give shape to their analysis of corporate law issues. ${ }^{238}$ In Britain, on the other hand, there is a tendency to acknowledge law and economics, cite its limitations and shift to a different theoretical ground. ${ }^{239}$ A typical move U.K. academics currently make is to discuss the company by reference to "stakeholder theory", which entails analyzing corporate issues by reference to employees and others potentially having a "stake" in a business (e.g. suppliers, customers and perhaps society at large). ${ }^{240}$

\section{Corporate Law Scholarship as Science}

With the key themes in corporate law scholarship duly accounted for, it is now possible to consider the extent to which the literature has evolved in accordance with the various potential trajectories considered in Part II of the paper. Let us begin with

237 Grantham, supra note xx, at 578-79; J.E. Parkinson, The Contractual Theory of the Company and the Protection of Non-Shareholder Interests in CORPORATE AND COMmercial LaW: Modern DeVElopments, 121, 121 (David Feldman and Frank Meisel, eds., 1996); Robert Yalden, Book Review 31 CAN. BuS. L.J. 479, 479, (1999); Michael Whincop, Painting the Corporate Cathedral: The Protection of Entitlements in Corporate Law, 19 OXFORD J. LEGAL ST. 19, 19-20 (1999).

$238 \quad$ Yalden, supra note $\mathrm{xx}$, at 479.

239 See, for example, PETTET, supra note xx, at 78-81; Parkinson, Contractual, supra note $\mathrm{xx}$, at 140-41; JANET Dine, THE GOVERNANCE OF CORPORATE GROUPS 1217 (2000). On why law and economics is treated with skepticism in the U.K., see David Campbell, Book Review, 24 J. LAw \& Soc. 574, 574-75 (1997); Richard Posner, The Future of the Law and Economics Movement in Europe, 17 INT'L REV. L. \& ECON. 3, 3-5 (1997). 
the accumulation of knowledge by scientific investigation. Again, the methodology involved is an enquiry founded upon the safeguards of explicit theory-building, replication and corroboration. ${ }^{241}$ Has this analytical technique had a substantial influence on the trajectory of corporate law scholarship? This question will now be assessed by examining circumstances where the explicit formulation and testing of hypotheses plausibly could have played a role.

Berle and Means' analysis of the corporate economy in the United States constitutes the first instance that merits consideration. A pivotal component of their work can certainly be characterized in scientific terms. Again, Berle and Means hypothesized that, at the time they were writing (1932), there was a separation of ownership and control in large companies in the U.S. They did not, however, leave matters at that. Instead, they sought to prove the point by defining when a corporation had sufficiently diffuse share ownership to qualify as management controlled and by finding out how equity was in fact distributed in the country's larger business enterprises. $^{242}$ Since Berle and Means' work had this strong empirical dimension, subsequent researchers could scrutinize their methodology and seek to affirm or refute the results by way of their own investigations. ${ }^{243}$ Correspondingly, The Modern Corporation and Private Property did have a scientific aspect.

240 PetTEt, supra note $\mathrm{xx}$, at 66, n. 105 (citing examples from the "immense" literature);

$241 \quad$ Supra note $\mathrm{xx}$ and related discussion.

242 BERLE AND MEANS, supra note xx, Book I, chs. 4, 5.

243 On efforts made to follow up on Berle and Means' empirical work, see Robert J. LARNER, MANAGEMENT CONTROL AND THE LARge CORPORATION 6-24 (1970). 
Still, the scientific credentials of Berle and Means' work must be kept in perspective. Contrary to what a scientist might have done, Berle and Means did not restrict themselves to describing an empirical phenomenon in value-free terminology. ${ }^{244}$ Instead, they condemned the separation of ownership and control in explicitly normative terms, identified lax corporate law doctrines as contributing to an allegedly abusive arrangement and suggested how tougher laws might improve matters. ${ }^{245}$ Legal academics examining the status of directors and shareholders subsequently went a step further and simply assumed there was a problem that needed to be solved and recommended increased regulation as a solution. ${ }^{246}$ Matters ultimately reached the point where corporate law scholarship lacked any genuine scientific pretensions. As law professor John Coffee observed in 1977:
"Although lawyers as a group are frequently inattentive to developments in allied social sciences, the field of corporation law presents an egregious example of cultural lag. Dominated by centuries-old fiduciary concepts...corporate law has not considered to any significant degree the relevance of social science.",247

The second instance where scientific methodology plausibly could have influenced corporate law scholarship involved the use of economic theory. Very soon

\footnotetext{
244 Johnston, Influence, supra note $\mathrm{xx}$, at 220.

245 See, for example, BERLE AND MEANS, supra note xx, Book II, chs. I-IV, VII.

246 Johnston, Influence, supra note $\mathrm{xx}$, at 219-29.

247 John C. Coffee, Beyond the Shut-Eyed Sentry: Toward a Theoretical View of Corporate Misconduct and an Effective Legal Response, 63 VA. L. REV. 1099, 110910 (1977).
} 
after Coffee bemoaned the minimal impact that social science was having on the corporate law field, the economic "prairie fire" began. ${ }^{248}$ Again, an alleged virtue of law and economics is that it allows for the accumulation of knowledge in a scientific fashion since empirically disprovable hypotheses can be produced and tested. ${ }^{249}$ Certain advocates of the economic approach to corporate law have indeed advanced this proposition in order to press the case in favor of contractarian analysis. ${ }^{250}$ Critics in turn were prepared to concede the point to some degree, saying that economic theory was a "valuable addition to the toolbox"251 and had left "the central underlying issues in corporate law exposed as never before." 252

In at least one respect, economic analysis indeed did make corporate law research more "scientific". The innovation in question was the introduction of event study methodology, which measures unexpected changes in share prices due to the adoption of new corporate law rules, judicial rulings or decisions taken by corporations. $^{253}$ Event studies have a scientific aspect because they provide researchers with the opportunity to formulate theories about the impact which a

248 Supra notes $\mathrm{xx}$ to $\mathrm{xx}$ and related text.

249 Supra note $\mathrm{xx}$ and accompanying discussion.

250 Johnston, Influence, supra note xx, at 239-40; Fred S. McChesney, Economics, Law, and Science in the Corporate Field, 89 CoLUM. L. REV. 1530, 1538 (1989).

251 Lyman Johnson, Individual and Collective Sovereignty in the Corporate Enterprise, 92 COLUM. L. REV. 2215, 2217-18 (1992).

252 Lawrence E. Mitchell, Groundwork of the Metaphysics of Corporate Law, 50 WASH. \& LEE L. REV. 1477, 1477 (1993).

253 Sanjai Bhagat and Roberta Romano, Event Studies and the Law: Part IIEmpirical Studies of Corporate Law, 4 AM. L. \& ECON. REV. 380, 381 (2002). 
particular action is likely to have on shareholders and then carry out testing by using share price fluctuations as a metric. Event study research has been carried out with increasing regularity since the 1980s and the result now is that no important topic of corporate governance has been left untouched. ${ }^{254}$

The invocation of economic analysis may well have introduced additional intellectual rigor to the study of corporate law. Nevertheless, the influence of scientific methodology should not be exaggerated. Event studies, for instance, are not necessarily models of experimental precision. Instead, their utility is intrinsically linked to contestable assumptions that share prices react quickly to new information and are a reliable indicator of firm value. ${ }^{255}$

Moving outside the realm of event studies, economically-oriented research on corporate law has shaky scientific credentials. If scientific methodology was truly influential, practitioners of the economic approach to corporate law would systematically generate the sort of predictions that can be verified or falsified on an empirical basis. ${ }^{256}$ Examples of this approach can certainly be found. For instance, over the past few years, various financial economists have used statistical measures of corporate law "quality" and cross-border data on share ownership to test the

254 Bhagat and Romano, Part II, supra note xx, at 382.

255 On the informational content of share prices and event studies, see Sanjai Bhagat and Roberta Romano, Event Studies and the Law: Part I - Technique and Corporate Litigation, 4 AM. L. \& ECON. REV. 141, 143 (2002) (saying, though, that event studies may be useful even if share prices do not adjust rapidly to new information). On the fact that it cannot be taken for granted that share prices are a reliable indicator of firm value, see ANDREI SHLEIFER, INEFFICIENT MARKETS: AN INTRODUCTION TO BEHAVIORAL FINANCE (2000). 
proposition that strong shareholder protection yields robust securities markets and a separation of ownership and control in large firms. ${ }^{257}$ The hypotheses advanced by economically-oriented corporate law academics have generally tended, however, to involve imprecise variables such as "third-party effects" and "transaction costs". 258 The danger correspondingly exists that their models can predict "any conceivable position that the law might take. No falsifiable conclusion has been reached; no act of science has been committed". ${ }^{259}$ We have already seen that doubts have been expressed about the scientific status of economic analysis of law. ${ }^{260}$ It would seem that, despite useful empirical work, concerns of this sort are justified in the particular context of corporate law.

\section{Corporate Law Paradigms}

Kuhn's characterization of knowledge evolving by reference to "normal science" and "paradigm shifts" has proved infectious outside the realm of natural science. ${ }^{261}$ Corporate law has not escaped the trend. Instead, various academics

256 Fred S. McChesney, Positive Economics and All That, 61 GEO. WASH. L. REV. 272, 281 (1992)

257 For overviews of the literature, see Stephen J. Choi, Law, Finance and Path Dependence: Developing Strong Securities Markets, 80 TEX. L. REV. 1657, 1672-73 (2002); Diane K. Denis and John J. McConnell, International Corporate Governance, 38 J. Fin. \& QuANTITATIVE ANAlysis, 1, 20-26 (2003)

258 McChesney, Positive, supra note xx, at 289-92 (reviewing EASTERBROOK AND FISCHEL, supra note $\mathrm{xx}$ ).

259 McChesney, Positive, supra note xx, at 292.

260 Supra note $\mathrm{xx}$ and accompanying text.

261 Supra note $\mathrm{xx}$ and related discussion. 
seeking to characterize intellectual trends in the field have relied on Kuhn's terminology. ${ }^{262}$

A plausible Kuhnian précis of corporate law scholarship can certainly be offered. It might proceed as follows. The debate over corporate personality that took place prior to 1930 would qualify as corporate law's "immature" phase since there was little agreement about how to define the corporation. ${ }^{263}$ Berle and Means' separation of ownership and control thesis then marked a decisive break because it was sufficiently convincing to become the dominant paradigm within the field of corporate law. ${ }^{264}$ After the emergence of the separation of ownership and control as a pivotal intellectual construct, a period of normal science followed where the focus was on regulatory strategies designed to address the "core" problem Berle and Means had identified.

According to Kuhn, the discovery of inexplicable "anomalies" that are irreconcilable with the dominant paradigm can puncture the consensus associated

262 See infra notes $\mathrm{xx}$ and $\mathrm{xx}$ and accompanying text.

263 "Paradigm" terminology has been used to describe the corporate personality debate: Stephen Bottomley, Taking Corporations Seriously: Some Considerations for Corporate Regulation, 19 FED. L. REV. 203, 206-13 (1990). This usage, however, is inconsistent with Kuhn's analytical framework since he assumed that consensus, not disagreement, was required for there to be a paradigm within the relevant field. For a more nuanced use of Kuhn's terminology with respect to the debate over corporate personality, see Mark, Personification, supra note xx, at 1466, n. 66.

264 Examples of those who have described Berle and Means' work in this way include Bratton, Economic, supra note xx, at 180; Carney, Legacy, supra note xx, at 217, 224; Thomas Lee Hazen, The Corporate Persona, Contract (and Market) Failure, and Moral Values, 69 N.C. L. REV. 273, 304 (1991). 
normal science. ${ }^{265}$ With the Berle and Means' paradigm, a paradox which emerged was that the separation of ownership and control had not created appreciable concern among those allegedly most affected, namely shareholders. ${ }^{266}$ Or as Henry Manne said in 1970:

“...if things were as Berle believed, it is very difficult to understand why 30 million Americans would continue to put money into the hands of corporate executives....We would have to assume that American investors were either the greatest collection of fools the world had ever seen or that they were charitable to a degree that even saints could not aspire to."267

Manne's explanation for what was going on was that corporate executives were not as unaccountable as they seemed. As he explained in a series of articles he wrote in the 1960s, market constraints, such as the market for corporate control, the capital market and product markets, served to curb managerial discretion. ${ }^{268}$

In Kuhnian terms, Manne's provocative critique of the received wisdom signaled a crisis within corporate law scholarship. ${ }^{269}$ A "scientific revolution" then

265 Supra note $\mathrm{xx}$ and accompanying text.

266 J.A.C. Hetherington, Fact and Legal Theory: Shareholders, Managers, and Corporate Social Responsibility, 21 STAN. L. REV. 248, 272 (1969); Robert Hessen, The Modern Corporation and Private Property: A Reappraisal, 26 J. L. \& ECON. 273, 288 (1983).

267 Manne, Myth, supra note xx, at 534.

268 On Manne's work on this topic, see Carney, Legacy, supra note xx, at 231-36.

269 Manne suggested that economic theory could explain the modern corporation by considering it as an efficient outcome of contacting parties. See, for example, Henry G. Manne, Current Views on the "Modern Corporation", 38 U. DET. L. REV. 
ensued, this being the emergence of the nexus of contracts model in the 1970s. The subsequent contractarian "prairie fire" then left economic analysis as the dominant paradigm in corporate law. ${ }^{270}$ Continuing to the present day, the academic study of corporate law currently is in a period of "normal science" where most theoretical analysis is conducted through the prism of economics. Nevertheless, the work being done on norms, the team production model and asset partitioning constitute sufficiently ambitious departures from the prevailing mode of analysis to suggest that the existing consensus might be unstable or eroding. ${ }^{271}$ Perhaps, then, a new "paradigm shift" is imminent. ${ }^{272}$

While it is certainly possible to rely on Kuhn's analytical framework to describe the evolution of academic writing on corporate law, the "fit" is far from perfect. Again, relying on Kuhn's work to characterize trends in legal scholarship involves a problematic leap in logic since he was focusing on scientific methodology

559, 583, 587-88 (1960); Henry G. Manne, The Higher Criticism of the Modern Corporation, 62 ColuM. L. REv. 399, 431 (1962). He did not, however, offer an affirmative theory that explained the modern corporation by reference to the criteria that characterized the economic analysis of markets. See Allen Kaufman and Lawrence Zacharias, From Trust to Contract: The Legal Language of Managerial Ideology, 1920-1980, 66 Bus. Hist. REV. 523, 546-47, 553 (1992).

270 For examples of those who have described contractarian analysis in these terms, see Bratton, Economic, supra note xx, at 180-81, 190; Whincop, Painting, supra note xx, at 27; Allen, Contracts, supra note xx, at 1401, 1406; Robert John Schulze, Can This Marriage be Saved? Reconciling Progressivism with Profits in Corporate Governance Laws, 49 STAN. L. REV. 1607, 1610 (1997).

$271 C f$. Johnson, Individual, supra note xx, at 2218 (offering the same verdict but referring to different aspects of corporate law theory).

272 Ulen, Nobel, supra note xx, at 886-87 (making the same point about economic analysis generally, referring to work which has been done in the field of behavioral economics). 
and this is not the dominant mode of enquiry in law. ${ }^{273}$ This objection is pertinent in the present context because, as we have just seen, the scientific credentials of corporate law research are shaky. ${ }^{274}$

Even if it is taken for granted that academic writing on law can be properly evaluated in Kuhnian terms, it may still not be appropriate to talk about the evolution of corporate law scholarship in terms of paradigms, normal science and so on. This is because the sort of tight research consensus that distinguishes a "mature" field of research from its "pre-paradigm" counterpart may have been lacking. Consider the nexus of contracts model which is currently dominant in American corporate law scholarship. Despite its pre-eminence, the efforts that are currently being made to expand the research agenda via the analysis of norms, trust and proprietary concepts illustrate that the model is not accepted on an unqualified basis. Also, there are various American corporate law academics who simply remain largely unconverted. $^{275}$

Taking the situation outside the U.S. into account casts even more doubt on the idea that corporate law can be thought of by reference to a tight research consensus. Berle and Means' work was the key point of departure in the U.S. from the 1930s to the 1980s. Elsewhere, however, the situation was different since

\footnotetext{
273 Supra notes $\mathrm{xx}$ to $\mathrm{xx}$ and related discussion.

274 Supra notes $\mathrm{xx}$ to $\mathrm{xx}$ and accompanying text.

275 Supra note $\mathrm{xx}$ and related discussion.
} 
academics focused almost entirely on doctrinal research. ${ }^{276}$ Turning to the present day, the nexus of contracts model is certainly influential in Canada and Australia as well as the U.S. ${ }^{277}$ In the United Kingdom, on the other hand, economic analysis is not dominant and in continental Europe it is only just beginning to establish a foothold. ${ }^{278}$ The upshot is that, unless one is prepared to treat an individual country such as the U.S. as the appropriate reference point, corporate law has consistently lacked the disciplinary matrix that Kuhn argued was required for academics to engage in "mopping up" activity. ${ }^{279}$

\section{E. Corporate Law Scholarship and the Marketplace for Ideas}

The assumption made earlier, if only for the sake of argument, was that there is scope for progress within legal scholarship. ${ }^{280}$ Under such conditions, a marketplace for ideas can potentially act as the catalyst for a move towards "better"

276 On the doctrinal focus outside the United States, see supra notes xx to xx and accompanying text. Still, the differences between the U.S. and other countries should not be overemphasized since up to the 1980s much American corporate law scholarship was doctrinally oriented: Johnson, Individual, supra note xx, at 2217; Charles R.T. O'Kelley, Foreword: The Many Passions of Teaching Corporations, 34 GA L. REV. 423, 426 (2000). Moreover, it would have been somewhat perverse if Berle and Means' work had set the agenda outside the U.S. since a separation of ownership and control is not the norm elsewhere. See Rafael La Porta et al., Investor Protection and Corporate Governance, 58 J. Fin. ECON. 3, 15 (2000).

$277 \quad$ Supra note $\mathrm{xx}$ and related discussion.

278 Supra notes $\mathrm{xx}$ to $\mathrm{xx}$ and accompanying text.

279 Perhaps, though, corporate law could be conceptualized in terms of a model derived from Kuhn known as the "multiparadigm perspective". On this notion, see Dennis A. Gioia, and Evelyn Pitre, Multiparadigm Perspectives on Theory Building, 15 ACAD. MgMt. REV. 584 (1990). 
academic writing on law. ${ }^{281}$ Is there evidence of a market-driven momentum towards "improvement" in the corporate law field? Though the case is not clear cut, there is indeed some.

First, the "bad" news on progress. Criticisms about unnecessary length and documentation have been leveled against legal scholarship. ${ }^{282}$ Such vices can certainly afflict academics writing about corporate law. For instance, an article in the closely related field of securities regulation that explored a single section of a single statute currently holds the record for the longest law review article. ${ }^{283}$

More generally, when matters are considered in historical terms, corporate law can legitimately stand accused of lacking a distinguished intellectual pedigree. According to one pessimist, as of 1962 "corporation law, as a field of intellectual effort, (was) dead in the United States". ${ }^{284}$ Matters seemingly had improved little by 1984, when Romano characterized corporate law as "an uninspiring field for research". 285

A similarly bleak prognosis has been offered at various junctures elsewhere. In Canada, in the mid-1980s critics of the country's corporate law scholarship decried

281 Supra notes $\mathrm{xx}$ to $\mathrm{xx}$ and related discussion.

282 Supra notes $\mathrm{xx}$ to $\mathrm{xx}$ and accompanying text.

283 Arnold S. Jacobs, An Analysis of Section 16 of the Securities Exchange Act of 1934, 32 N.Y.L. SCH. L. REV. 209 (1987), which is over 490 pages in length and has some 4800 footnotes. On its status as the article with the most footnotes, see Rhode, supra note xx, at 1334-35; Lasson, Scholarship, supra note xx, at 937-38.

284 Bayless Manning, The Shareholder's Appraisal Remedy: An Essay for Frank Coker, 72 YALE L.J. 223, 245, n. 37 (1962). 
the "invisibility of contextual and theoretical influences" and alleged that the "choice of topics and methods for scholarly examination appears to have generally been an unsystematized exercise of personal preferences." ${ }^{286}$ In Britain, company law was not even recognized as a respectable academic subject until at least the 1950 s. $^{287}$ With respect to the rest of Europe, in 2000 a reviewer of a book on corporate governance bemoaned "the hermetically sealed doctrinal analysis common in Continental, and especially German law". ${ }^{288}$

Now, the "good" news: the pessimism about corporate law scholarship has dissipated to a significant degree. Dan Prentice, a leading British company law scholar, remarked in 1993 that academic writing on the topic had "improved immeasurably in terms of quality" during the previous decade. ${ }^{289}$ Robert Yalden, a Canadian legal practitioner, argued in 1999 that "the level and quality of scholarship concerning Canadian corporate law ha(d) improved considerably in the past years 30 years". ${ }^{290}$ With respect to the United States, in 1992 Romano reversed her pessimistic 1984 appraisal, saying that corporate law had undergone "a revolution over the past

285 Romano, Metapoliticssupra note xx, at 923.

$286 \quad$ Lahey and Salter, Corporate Law, supra note xx, at 569.

287 Caroline Bradley and Judith Freedman, Changing Company Law, 53 MoD. L. REV. 397, 398 (1990); C.A. Riley, Gower: Still a Blueprint for Curriculum Reform in Company Law?, 13 OXFORD J. LEGAL STUD. 271, 271 (1993).

288 Cioffi, State, supra note $\mathrm{xx}$, at 509.

289 D.D. Prentice, Some Observations on the Teaching of Company Law, in EXAmining the Syllabus: Beyond the CoRE, 33, 35 (P.B.H. Birks ed., 1993).

290 Yalden, supra note $\mathrm{xx}$, at 479. See also Richard W. Bauman, Liberalism and Canadian Corporate Law, in CANADIAN PERSPECTIVES ON LEGAL THEORY, 75, 75 
decade". ${ }^{291}$ Richard Buxbaum, another U.S. law professor, said in 1993 that a new generation of corporate law academics was "tearing up the track and making corporation law the hottest game in town". ${ }^{292}$ Deborah DeMott, also an American legal academic, echoed the same sentiments in 1996. She said that there had been "invigorated discussion and deepened analysis" in a field where the literature had been "uninspiring" and "parochial" in scope. ${ }^{293}$

Those who have argued that there has been a beneficial transformation of corporate law scholarship in recent years have generally acknowledged that the invocation of economic analysis has had a pivotal influence. For instance, Yalden noted "that the law and economics movement has had a profound impact on the way in which corporate law is taught in Canada" ${ }^{294}$ and Prentice explicitly recognized the substantial effect economic analysis has had on corporate law scholarship. ${ }^{295}$ Similarly, in the United States, the economic approach to corporate law has been

(Richard F. Devlin ed., 1991) (referring to a "recent rebirth of a combined intellectual and political approach to corporate doctrine and scholarship").

291 Roberta Romano, Preface, in Foundations of Corporate LAw, v, v (Roberta Romano ed., 1992).

292 Richard M. Buxbaum, New Owners and Old Managers: Lessons from the Socialist Camp, 18 DEL. J. CORP. L. 867, 868 (1993).

293 Deborah A. DeMott, Trust and Tension Within Corporations, 81 CoRNELL L. REV. 1308, 1308, 1335 (1996).

$294 \quad$ Yalden, supra note $\mathrm{xx}$, at 479.

295 Prentice, supra note $\mathrm{xx}$, at 35. 
credited for revitalizing "among the sleepiest of legal fields". ${ }^{296}$ As Lyman Johnson, a self-confessed law and economics septic, said in 1992 about economic analysis:
"Few can doubt that corporate law - long a field heavily doctrinaire and almost nontheoretical - has forever been changed (and bettered) over the past dozen years by this infusion", 297

Romano, Buxbaum and DeMott each offered a similar verdict when giving their optimistic appraisals of corporate law scholarship. ${ }^{298}$ The upshot is that, even if "progress" cannot be taken for granted in the area of corporate law, there is a widespread belief that the admittedly controversial law and economics "prairie fire" did yield a "better" understanding of the topics under investigation.

\section{F. Corporate Law Cycles}

The admittedly optimistic characterization of corporate law scholarship just presented has a potentially weak foundation since the underlying premise was that "progress" results from a marketplace for ideas. Market failure may, however, be prevalent in the area of legal scholarship. ${ }^{299}$ Correspondingly, it cannot be taken for granted that things really have gotten "better" or, if they have, they will continue to do so. An alternate scenario that merits consideration is that much of what is being said

\footnotetext{
296 Johnston, Influence, supra note xx, at 219.

297 Johnson, Individual, supra note xx, at 2217. On Johnson's skepticism towards economics, see id. at 2217-18.
}

298 Romano, Preface, supra note xx, at 5; Buxbaum, supra note xx, at 868; DeMott, supra note xx, at 1312, 1335. See also Mitchell, Groundwork, supra note xx, at 1477, 1481-82; O'Kelley, Forewordsupra note xx, at 426. 
now has been said before. This is because a potential trajectory for legal scholarship is cyclical, in the sense that the literature constitutes a continuing conversation about pivotal questions. $^{300}$

This possibility has in fact been recognized in corporate law scholarship. As one corporate lawyer observed in a law review article published in 1991, “(o)ne of the characteristics of corporation law, and indeed, perhaps of life, is that few issues are ever settled conclusively". ${ }^{301}$ Similar sentiments were echoed in another essay published a few years earlier, where it was said that, because of the "ebb and flow of popular conceptions”, “(t)o address the future of corporation law, we must look first to the past". 302

The question "what is a corporation?" illustrates that the cyclical perspective is potentially instructive. ${ }^{303}$ For instance, the nexus of contracts model that has been so influential in the past two decades has rhetoric in common with the "contractual/association" thesis that was being offered in the early $20^{\text {th }}$ century. ${ }^{304}$

299 Supra notes $\mathrm{xx}$ to $\mathrm{xx}$ and accompanying text.

$300 \quad$ Supra notes $\mathrm{xx}$ to $\mathrm{xx}$ and related discussion.

301 A.A. Sommer, Whom Should the Corporation Serve? The Berle-Dodd Debate Revisited Sixty Years Later, 16 DEL. J. CoRP. L. 33, 33 (1991). See also William T. Allen, Our Schizophrenic Conception of the Business Corporation, 14 CARDOZO L. REV. 261, 278-81 (1992); Eric W. Orts, The Complexity and Legitimacy of Corporate Law, 50 WASH. \& LEE L. REV. 1565, 1571 (1993).

302 Elliott Goldstein, Future Articulation of Corporation Law, 39 BUS. LAw. 1541, 1541 (1984).

303 Allen, Our, supra note xx, 280-81.

304 See Bratton, New, supra note xx, 1472-73, 1513-15, 1526; Gregory A. Mark, Some Observations on Writing the Legal History of the Corporation in the Age of 
Also, there may be links between the "fiction" theory that corporate organizations owe their existence to an official grant of authority from the state and Hansmann and Kraakman's contemporary work concerning asset partitioning. ${ }^{305}$ This is because both imply the state makes available to those relying on the corporate form something that could not be attained privately. ${ }^{306}$

“Are managers sufficiently accountable?" and "on whose behalf are companies run?" qualify as two additional questions that illustrate the potentially cyclical quality of corporate law scholarship. ${ }^{307}$ With respect to managerial accountability, as we have seen, Berle and Means' The Modern and Corporation and Private Property flagged this as a pivotal topic. ${ }^{308}$ Until the 1980 s, the consensus was

Theory, in PROGRESSIVE (Mitchell), supra note xx, 67, 72-73; Carl Landauer, Beyond the Law and Economics Style: Advancing Corporate Law in an Era of Downsizing and Corporate Reengineering, 84 CAL. L. REV. 1693, 1709-10 (1996).

305 See supra notes $\mathrm{xx}$ to $\mathrm{xx}$ (fiction theory) and supra notes $\mathrm{xx}$ to $\mathrm{xx}$ (asset partitioning) and accompanying text. For additional arguments that the fiction theory might have contemporary relevance, see Fiona Macmillan Patfield, Challenges for Company Law, in PERSPECTIVES ON COMPANY LAW: 1 1, 8-9 (Fiona Macmillan Patfield ed., 1995); Jennifer Hill, Visions and Revisions of the Shareholder, 48 AM. J. COMP. L. 39, 56-57 (2000).

306 Note, though, that Hansmann and Kraakman downplay links between their asset-oriented analysis on the one hand and theories of juridical personality on the other: Hansmann and Kraakman, Essential, supra note xx, at 438-39.

307 An additional example involves shareholder voting rights. In the 1950s, a popular view was that shareholders' voting rights be abolished, but by the mid-1980s it was said that "in the wake of the tumultuous take-over wars of recent years, these views are unlikely to be put forward again, at least in the immediate future": Hetherington, Redefining, supra note xx, at 235. By 1999, though, Blair and Stout were wondering " $(\mathrm{w})$ hy does corporate law provide for shareholder voting rights at all?": Team, supra note $\mathrm{xx}$, at 312.

308 Supra notes $\mathrm{xx}$ to $\mathrm{xx}$ and related discussion. 
that state intervention was required to keep corporate executives in line. ${ }^{309}$

Contractarians subsequently adopted a more deregulatory posture but nevertheless did continue to focus on managerial accountability via agency cost theory. ${ }^{310}$ Corporate governance scandals afflicting major American companies such as Enron Corp. have kept the topic in the spotlight and might ultimately yield a intellectual pendulum swing back in favor of tighter regulation. ${ }^{311}$

Turning to corporate goals and responsibilities, legal debates on this stretch from the 1930s to the present day. ${ }^{312}$ The prevailing view under U.S. law is that companies exist for their shareholders. ${ }^{313}$ Some inferred from Berle and Means' work, though, that companies must have obligations that extend beyond those owning equity. ${ }^{314}$ Contractual analysis was subsequently invoked to support the status quo.

$309 \quad$ Supra notes $\mathrm{xx}$ to $\mathrm{xx}$ and accompanying text.

$310 \quad$ Supra notes $\mathrm{xx}$ to $\mathrm{xx}$ and related discussion.

311 Alfred P. Carlton, $21^{\text {st }}$ Century Corporate Responsibility - "Evolution, Revolution, or Back to the Future, 54 MERCER L. REV. 671, 672-73 (2002); for a plea that a "pendulum-like movement" be avoided, see Bengt Holmstrom and Steven N. Kaplan, The State of U.S. Corporate Governance: What's Right and What's Wrong?, J. APPLIED CORP. FIn., Spring 2003, at 8, 20. The cyclical quality of debates on managerial accountability has been recognized elsewhere. See, for example, Bratton, Berle, supra note xx, 755-56; Bratton, Economic, supra note xx, 182; David Millon, Redefining Corporate Law, 24 IND. L. REV. 223, 225 (1991).

312 Stout, Bad, supra note xx, at 1189-90, 1208; C.A. Harwell Wells, The Cycles of Corporate Social Responsibility: An Historical Retrospective for the Twenty-first Century, 51 U. KAN. L. REV. 77, 78-79, 82 (2002).

313 Supra notes $\mathrm{xx}$ to $\mathrm{xx}$ and related discussion.

314 Supra notes $\mathrm{xx}$ to $\mathrm{xx}$ and accompanying text. 
Following on from this, the team production model and stakeholder-oriented scholarship currently offer a challenge to the notion of shareholder primacy. ${ }^{315}$

It may well be that in the area of corporate law there are certain questions which have endured as topics and will continue to do so. Hence, it seems quite likely that in future decades academics will be asking "what is a corporation?", "are managers sufficiently accountable?" and "on whose behalf are companies run?" 316 Still, caution is required so as to avoid attaching undue weight to a cyclical account of corporate law theory.

One reason to be circumspect is that the existence of perennial issues does not necessarily displace other potential trajectories we have considered thus far. For instance, the presence of enduring questions can be consistent with evolution along Kuhnian lines. This is because in order for a paradigm shift to occur, the new theory must not only be able to cope with the anomalies that caused a crisis for the old theory but also must address satisfactorily most, if not all, familiar problems. ${ }^{317}$

\footnotetext{
315 Supra notes $\mathrm{xx}$ to $\mathrm{xx}$ and related discussion. On the team production model as a component of the long-standing debates on corporate social responsibility, see Wells, Cycles, supra note xx, at 136-39; Stout, Bad, supra note xx, at 1195. For additional background on the cyclical quality of debates on corporate goals and responsibilities, see Branson, Corporate, supra note xx, at 635-39; Sommer, Whom, supra note $\mathrm{xx}$, at 33-36; Roberta S. Karmel, The Independent Corporate Board: A Means to What End?, 52 GEO. WASH. L. REV. 534, 535-43 (1984).
}

316 William A. Bratton, Never Trust a Corporation, 70 GEO. WASH. L. REV. 867, 867 (2002) ("corporate responsibility is problem that never goes away...from policy agendas in academic corporate law").

317 KUHN, supra note $\mathrm{xx}, 153,169$. On the other hand, a cyclical account does not square fully with the Kuhnian characterization of science, since he argued that scientific development should be "a unidirectional and irreversible process": $I d$. at 206. 
Similarly, though a cyclical trajectory has a pessimistic connotation, ${ }^{318}$ the presence of enduring questions does not necessarily preclude potential "progress". Consider managerial accountability. ${ }^{319}$ Contractarians admittedly explored issues that Berle and Means' separation of ownership and control thesis had already raised. Still, the effort to put corporate law on a different theoretical footing did have an effect on the discourse. ${ }^{320}$ Arguably, the explicit recognition of market forces constituted an intellectual advance since the resulting scholarship addressed a key paradox associated with the initial formulation of the separation of ownership and control thesis. ${ }^{321}$ This, again, is why did generations of investors continue to buy shares when they were being fooled or overpowered by self-serving executives? ${ }^{322}$

An additional reason a cyclical account of academic writing on corporate law should be treated with caution is that uncritical acceptance of this point of view might create a misleading impression of stability and predictability. To elaborate, there may well be much more going on than the revisiting of the same issues again and again. Instead, it may be that "future contours of corporate legal theory are imponderable". ${ }^{323}$ Past experience illustrates that the potential certainly exists for

318 Supra note $\mathrm{xx}$ and accompanying text

319 The same point can potentially be made in relation to corporate goals and responsibilities: Stout, Bad, supra note xx, at 1208 (arguing that even if the debate about the purpose of the corporation which has been going on since the 1930s has not been resolved, "there has been some progress in our understanding of it").

320 Bratton, Economic, supra note xx, at 182, n. 18.

321 Johnston, Influence, supra note xx, at 231-41.

322 Supra note $\mathrm{xx}$ and related discussion.

323 DeMott, Trust, supra note xx, at 1335. 
movements in apparently random directions. ${ }^{324}$ For instance, an academic writing at the beginning of the 1970s who forecast that an economically-oriented "prairie fire" was imminent probably would have been dismissed as foolish. A prediction made a decade or more later about the current interest in the study of social norms might well have yielded similar ridicule. ${ }^{325}$ It is fair to say, then, that one cannot outline how corporate law scholarship will evolve in the future simply by considering the past.

G. Fads and Fashions in Corporate Law

The fact that seemingly unpredictable trends have emerged in the academic literature on corporate law does more than cast doubt on a cyclical account of literature in the discipline. This pattern suggests also that the field might be subject to fads and fashions. This is because Cass Sunstein, in arguing that "cascades" influence legal scholarship, maintains this means that it is difficult to foresee new trends in the academic study of law. He reasons that, as in social life, "small sparks cause wildfires" in legal scholarship. ${ }^{326}$ Correspondingly, seemingly random movements "can produce a sudden 'rush' toward a particular methodology or point of view".,327

There certainly are aspects of corporate law scholarship that fall into line with Sunstein's analysis of legal scholarship. For instance, he asserts that external shocks

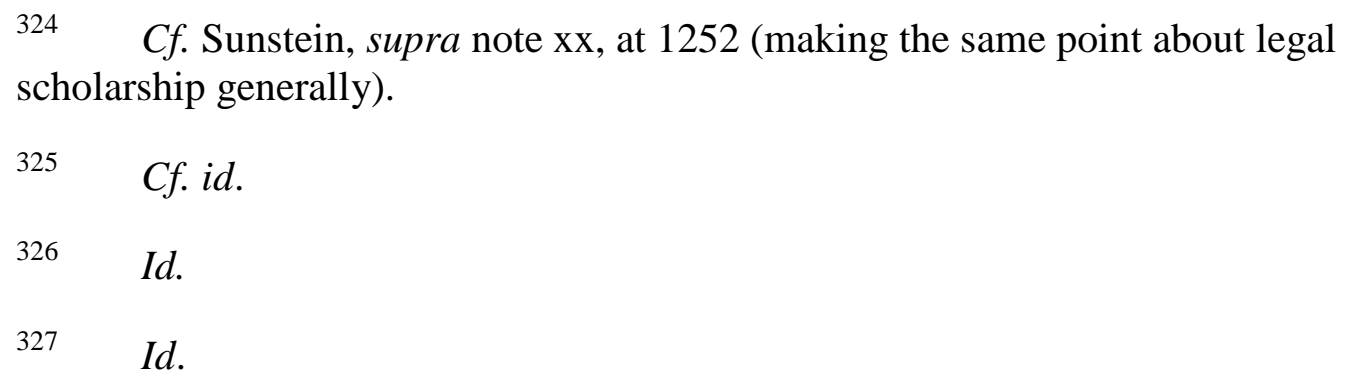


can constitute a crucial reason why an academic bandwagon might start. ${ }^{328}$ The influence which Berle and Means' work on the separation of ownership and control had can be accounted for at least partially on this basis. In the 1920s, some observers drew attention to growing dispersion of share ownership and to the erosion of shareholder influence. ${ }^{329}$ These efforts were not ignored but failed to capture the imagination in the same manner Berle and Means' analysis did. ${ }^{330}$ The stock market crash of 1929 and the ensuing Depression likely constituted a crucial intervening feature. The audience for The Modern Corporation and Private Property likely was much more alert and receptive to Berle and Means' critical analysis of revolutionary changes affecting U.S. corporations than would have been the case in better economic times. $^{331}$

External shocks also plausibly contributed to the popularity of the nexus of contracts model. According to Sunstein, developments in adjacent fields can help to prompt an academic cascade. ${ }^{332}$ This characterization is potentially apt for the economic analysis of corporate law. This is because the work which economists began to do in the 1970s on the market dynamics functioning within firms provided

$328 \quad I d$. at 1262.

329 Tsuk, supra note xx, at 1883; Walter Werner, Management, Stock Market and Corporate Reform: Berle and Means Reconsidered, 77 COLUM. L. REV. 388, 394-95 (1977); George J. Stigler and Claire Friedland, The Literature of Economics: The Case of Berle and Means, 26 J.L. \& ECON. 237, 241 (1983).

330 Stigler and Friedland, supra note xx, at 241-42.

331 Werner, Management, supra note xx, at 395; Joseph L. Weiner, The BerleDodd Dialogue on the Concept of the Corporation, 64 CoLuM. L. REV. 1458, 1461 (1964); Robert Hessen, The Modern Corporation and Private Property: A Reappraisal, 26 J. L. \& ECON. 273, 279 (1983). 
the platform for the contractarian "prairie fire" which subsequently swept the corporate law field. ${ }^{333}$

The general intellectual climate may also have constituted an external shock that contributed to the "victory" of economic analysis. There was a growing disenchantment with government regulation in the U.S. during the 1980s and, coincident with this, the analysis of private law issues was marked by an increasingly market-oriented conservatism. ${ }^{334}$ Corporate law scholarship fell directly into line with such trends. ${ }^{335}$ This is because academics embracing the nexus of contracts concept tended to presume that, as compared with government regulators, business participants typically do a better job of structuring transactions and addressing potentially contentious issues. ${ }^{336}$

Another aspect of Sunstein's analysis of academic fads which is potentially pertinent for corporate law scholarship involves the presence of strongly-held views in

$332 \quad$ Sunstein, supra note $\mathrm{xx}$, at 1262.
$333 \quad$ Supra notes xx to xx and related discussion.
$334 \quad$ Elaine A. Welle, Freedom of Contract and the Securities Laws: Opting Out of Securities Regulation by Private Agreement, 56 WASH. \& LEE L. REV. 519, 524-25 (1999).

335 Bratton, New, supra note $\mathrm{xx}$, at 1524-25; Tsuk, supra note $\mathrm{xx}$, at 1904;

Cynthia A. Williams, Corporate Compliance with the Law in the Era of Efficiency, 76 N.C. L. REV. 1265, 1287-88 (1998).

336 Robert B. Thompson, The Law's Limits on Contracts in a Corporation, 15 J. CoRP. L. 377, 388 (1990); Robert A. HiLlmAN, THE Richness OF CONTRACT LAW: AN ANALYSIS AND CRITIQUE OF CONTEMPORARY THEORIES OF CONTRACT LAW, 98-99 (1997). For examples of deregulatory bias, see Hetherington, Redefining, supra note xx, at 251-54, 257; McChesney, Economics, supra note xx, at 1544, 1548; Frank H. Easterbrook and Daniel R. Fischel, The Corporate Contract, 89 COLUM. L. REV. 1416, 1442 (1989). 
an academic environment. Sunstein describes the emergence and durability of fads in terms of reputational pressures and "group polarization", where a like-minded group moves collectively via mutual self-reinforcement towards an extreme position. ${ }^{337}$ The skepticism towards dissent implied by this characterization of academic thought has arguably been evident in the area of corporate law. For instance, when the separation of ownership and control thesis was the intellectual point of departure, most legal academics reacted with "cold disdain" to Manne's critique of the managerialist thesis of the public corporation. ${ }^{338}$ Moving to the present, as we have seen, in the U.S. corporate law scholarship allegedly cannot succeed in the marketplace of ideas unless an economics of law perspective has been adopted. ${ }^{339}$

Assume, for the sake of argument, that there can be fads in the corporate law literature. This still leaves open a key point concerning Sunstein's analysis of legal scholarship. Again, he is something of a "cascade pessimist" because he believes that bad ideas can potentially prosper for a long period of time. ${ }^{340}$ In other words, durability is not a reliable signal of quality. More broadly, it cannot be taken for granted that ideas which become dominant within a discipline represent "progress" in any meaningful sense. Instead, they may simply be the product of a bandwagon effect built upon a "wrong" outcome. Applying this insight to the contemporary analysis of corporate law, the inference one can draw is that the economic approach which has

\footnotetext{
337 Supra notes $\mathrm{xx}$ to $\mathrm{xx}$ and accompanying text.

338 Manne, Intellectual, supra note xx, at 229.

339 Supra note $\mathrm{xx}$ and related discussion.

340 Supra notes $\mathrm{xx}$ to $\mathrm{xx}$ and accompanying text.
} 
predominated in the literature for the past two decades (at least in the U.S.) has not done so because of the inherent merits of this mode of analysis.

Is cascade pessimism appropriate in this instance? Perhaps not. The views expressed by critics of economic analysis are potentially revealing. When the nexus of contracts model was novel, skeptics acknowledged that it was fashionable but said it was destined to fade away quickly. For instance, one U.S. law professor proclaimed in 1988 that "the original contract paradigm had outlived its usefulness" "341 and another subsequently said its advocates should "retool" and become "teachers of family law, or land use, or take up golf or serious gardening". 342 Moreover, this was the fate that was deserved since the economic approach to corporate law was flawed. As Melvin Eisenberg, a prominent critic, declared in 1990, “(t)he brute fact is that contractarian theory can have no meaningful application to an institution, like the publicly held corporation, that is essentially non-contractual in orientation". 343

Now the tone of debate has changed, at least in the U.S. Increasingly, the nexus of contracts model has been accepted as a pivotal analytical construct. Indeed, as mentioned, those with misgivings tend to use it as a point of departure rather than

341 Bratton, Economic, supra note xx, at 197.

342 Douglas M. Branson, The Death of Contractarianism and the Vindication of Structure and Authority in Corporate Governance and Corporate Law, in PROGRESSIVE (Mitchell), supra note xx, 93, at 105. See also Johnson, supra note xx, at 2218; Orts, Complexity, supra note xx, at 1569.

343 Melvin A. Eisenberg, Contractarianism Without Contracts: A Response to Prfessor McChesney , 90 ColuM. L. REV. 1321, 1331 (1990). See further supra note $\mathrm{xx}$ and accompanying text. 
seeking to dismiss it categorically. ${ }^{344}$ Melvin Eisenberg's approach is illustrative. Though he retained his skepticism of the contractarian approach, by 1999 he was prepared to concede that the model was influential and captured at least a partial view of reality. ${ }^{345}$ Since even critics of economic analysis have been prepared to concede that it has made a helpful contribution, this may well not be an instance where a "bad" idea has prospered for a long period of time.

In the area of corporate law, the fact that a durable theory such as the nexus of contracts model seemingly has intellectual merit may not be a coincidence. Since the arrival of new information can correct quite quickly an initially mistaken cascade, a factor which likely influences the extent to which misguided academic fads persist is the "open" or "closed" nature of the intellectual discourse. ${ }^{346}$ Correspondingly, erroneous legal scholarship bandwagons should be more vulnerable to displacement when practicing lawyers and judges engage with the literature than when the relevant field is specialized, insulated and purely academic. Richard Posner, as we have seen, has made this point by contrasting interdisciplinary legal scholarship dealing with moral philosophy (a closed network) and bankruptcy law (an open network). ${ }^{347}$

Assuming that the "open" or "closed" nature of discourse does influence the longevity of a mistaken fad, corporate law is a field where cascade optimism is appropriate. This is because, as with bankruptcy law, the intellectual network is

\footnotetext{
$344 \quad$ Supra note $\mathrm{xx}$ and related discussion.

345 Eisenberg, Conception, supra note xx, at 818, 823, 827, 829; see also Millon, New, supra note $\mathrm{xx}$, at 57.

$346 \quad$ Supra note $\mathrm{xx}$ and related discussion.
} 
outward looking, with there being an audience for theoretical corporate law scholarship outside law faculties. ${ }^{348}$ For example, in the United States allegedly "judicial opinions and practitioner publications are filled with the jargon of law and economics". 349 Also, Thomas Ulen, an expert on the economic analysis of law, has said about the corporate field that he is "not aware of any other area of the law where the connection between innovations in legal scholarship and the work of practitioners, judges and policy-makers has been quite so clear". ${ }^{350}$ Even in the United Kingdom, where economic analysis has not had a substantial influence on corporate law scholarship, ${ }^{351}$ during the late 1990s the English and Scottish Law Commissions secured a contribution from law and economics experts as part of a review of the duties of company directors. ${ }^{352}$

The "open" nature of the intellectual discourse on corporate law is not a coincidence. Instead, academics in the field -- including those who adopt an

$347 \quad$ Supra notes $\mathrm{xx}$ to $\mathrm{xx}$ and accompanying text.

348 Cheffins, Using, supra note xx, at 214-15.

349 Stephen Bainbridge, Community and Statism: A Conservative Contractarian Critique of Progressive Corporate Law Scholarship, 82 CORNELL L. REV. 856, 85859 (1997).

350 Thomas Ulen, The Coasean Firm in Law and Economics, 18 J. CORP. L. 301, 331 (1993).

$351 \quad$ Supra note $\mathrm{xx}$ and accompanying text.

352 LAW COMMISSION AND SCOTTISH LAW COMMISSION, COMPANY DIRECTORS: REgulating CONFLICTS OF INTERESTS AND FoRMUlating a STATEMENT OF DUTIES (Law Commission Consultation Paper No. 153), (1998), Part 3. 
interdisciplinary approach -- are keen to engage issues of practical interest. ${ }^{353}$ As Deborah DeMott has said, "the recent literature (on corporate law) eagerly embraces as topics for study all manner of current developments in business and financial practice". ${ }^{354}$ Assuming that "open" and "closed" discourse yield different outcomes with respect to academic fads, the strong link between practice and theory in the corporate law field suggests that "cascade optimism" is appropriate. DeMott essentially concurs with this verdict, saying that the fact "current practice intrigues theoretically-oriented academics helps ensure that corporate law scholarship will not run dry". 355

\section{CONCLUSION}

In recent decades, there has been an explosion in legal scholarship marked by the proliferation of new law reviews and the growing use of interdisciplinary analysis. ${ }^{356}$ Still, there has been little systematic analysis of the manner in which academic writing on law evolves over time. This paper's purpose has been to address this gap and offer insights concerning the development of legal scholarship. The first

353 For an example of an explicit acknowledgement of such an intention, see Lyman Johnson, New Approaches to Corporate Law, 50 WASH. \& LEE L. REV. 1713, 1723 (1993).

354 DeMott, supra note $\mathrm{xx}, 1335$.

$355 \quad I d$.

356 Philip C. Kissam, The Decline of Law School Professionalism, 134 U. PA. L. ReV. 251, 297 (1986); Charles W. Collier, The Use and Abuse of Humanistic Theory in Law: Reexamining the Assumptions of Interdisciplinary Legal Scholarship, 41 Duke L.J. 191, 203 (1991); Joseph P. Tomain and Paul L. Caron, The Associate Dean for Faculty Research Position: Encouraging and Promoting Scholarship, 33 U. TOL. L. REV. 233, 237 (2001) (saying that if the "proliferation continues there will eventually be more law reviews than law teachers"). 
step was to identify five potential trajectories. Part II's overview of the field indicates that all are plausible to at least some degree. At the same time, no single account is fully convincing. ${ }^{357}$ Moreover, the various options yield lessons that are, at least in some measure, contradictory. ${ }^{358}$

To address such paradoxes and to shed light on the manner in which academic writing on law evolves, part III of the paper presented a case study of corporate law. The analysis offered confirms that each of the trajectories identified in part II can be relied upon to explain the evolution of corporate law scholarship. For instance, Berle and Means' pioneering work on the separation of ownership and control was at least partially scientific in its approach and the use of event studies helps to ensure that formal verification of hypotheses is a component of the contemporary theoretical literature. With Kuhn's work, characterizing corporate law scholarship in terms of paradigms, normal science and so on has proved to be a popular endeavor. The marketplace for ideas may have had a beneficial impact on the literature since academic writing on corporate law has arguably become "better", particularly in the past two or three decades. At the same time, the presence of enduring questions has meant the literature has a cyclical aspect. Finally, external shocks, reputational constraints and perhaps even "group polarization" have had an influence on corporate law scholarship, which implies that trends in the literature resemble fads or fashions.

In addition to illustrating that each of the trajectories outlined in part II offers insights concerning the evolution of legal scholarship, the case study in part III

\footnotetext{
$357 \quad$ See supra note $\mathrm{xx}$ and related discussion.

358 See supra note $\mathrm{xx}$ and accompanying text.
} 
affirmed that each has its limitations. For example, much of the academic literature on corporate law is too normative in orientation to qualify as scientific enquiry. Kuhn's analytical framework may not be directly relevant because the field has arguably lacked the sort of tight research consensus required for concepts such as "paradigms" and "normal science" to be relevant. The hallmarks of "market failure" that afflict legal scholarship generally are pertinent with respect to corporate law, which implies that it cannot be taken for granted that the forces of supply and demand will yield "progress". Since the "future contours of corporate legal theory are imponderable", ${ }^{359}$ a cyclical account of academic writing on the topic must necessarily be incomplete to some degree. Finally, while applying terminology such as "fads" and "fashions" to academic concepts might imply superficiality, the "open" nature of corporate law discourse suggests theoretical approaches which become popular and endure are likely to have some form of intrinsic merit.

A potential objection to the inferences drawn from the case study of corporate law is that the sample was not representative. To the extent that this is true, trajectories that seem to be a good "fit" with corporate law may be irrelevant with respect to other areas. To illustrate, while the profound influence which law and economics has had on corporate law scholarship means that a credible argument can be made that scientifically-oriented progress has been made in the field, there will be areas of the law where the situation will be different. For instance, empirical methodology, with an attendant emphasis on verification and falsification, has

359 See supra note $\mathrm{xx}$ and related discussion. 
apparently had little impact on constitutional or family law. ${ }^{360}$ In fields such as these, the trajectory of scholarship may entirely lack a scientific angle.

It is unrealistic to expect that legal scholarship would develop at the same pace in all fields. Instead, there will inevitably be some unevenness in the overall development and maturity of particular areas. ${ }^{361}$ Correspondingly, it should not be surprising that there are fields with trajectories somewhat different from corporate law. This possibility does not necessarily undermine the value of the case study offered here, since it is unlikely that the academic writing associated with any particular area of the law could be perfectly representative of legal scholarship at large. There would, however, be a serious problem if corporate law was profoundly out-of-step with general trends. To take one example, tax would have been a problematic choice for a case study since the relevant literature is allegedly significantly behind the curve within the legal academy. ${ }^{362}$

With respect to corporate law, there admittedly has traditionally been something of a tendency within the legal academy to treat it as a lesser subject. ${ }^{363}$ Indeed, until two or three decades ago, academics in the field were essentially

$360 \quad$ Heise, Past, supra note xx, at 819, 826; Ronald J. Allen, Two Aspects of Law and Theory, 37 SAN DIEGo L. REV. 743, 745 (2000); Barry Friedman, The CounterMajoritarian Problem and the Pathology of Constitutional Scholarship, 94 Nw. U.L. REV. 933, 933, 951-52 (2001) (focusing on constitutional law).

361 Heise, Past, supra note $\mathrm{xx}$, at 826.

362 Michael A. Livingston, Reinventing Tax Scholarship: Lawyers, Economists, and the Role of the Legal Academy, 83 CORNELL L. REV. 365, 383 (1998). 
concurring with this gloomy assessment. ${ }^{364}$ Still, as we have seen, the subject has benefited from something of an intellectual renaissance in the period since. ${ }^{365}$ This, in turn, likely means that corporate law is in fact no longer seriously behind the curve. ${ }^{366}$ Correspondingly, the case study offered in part III likely does constitute a fair test of the trajectories outlined in part II and correspondingly lends legitimate support to the proposition that each is a plausible driver, albeit within limits.

For those seeking decisive answers concerning the trajectory of legal scholarship, the tentative nature of the conclusions offered here might be somewhat disappointing. A clear-cut outcome was not, however, really a serious prospect. After all, there is "no jurisprudence of legal scholarship" and drawing firm conclusions without additional evidence concerning particular subject areas would have been imprudent. Given these caveats, the appropriate way to interpret the findings offered here is as a first step in a larger intellectual enquiry. A series of plausible trajectories for legal scholarship has been identified and explained.

Moreover, the case study of corporate law has confirmed that, to varying degrees, each is credible. Correspondingly, for those who are interested in why ideas spread and prosper whereas other claims "burn out", this paper offers a "test-driven"

364 Supra notes $\mathrm{xx}$ to $\mathrm{xx}$ and related discussion.

365 See supra notes $\mathrm{xx}$ to $\mathrm{xx}$ and accompanying text.

366 Livingston, Reinventing, supra note $\mathrm{xx}$, at 385 (acknowledging that corporate law scholarship is, in key respects, significantly ahead of tax scholarship). Corporate law scholarship may even be ahead of the curve in certain respects. See, for example, Ulen, Nobel, supra note xx, at 911 (saying that academic debate might be helping to foster convergence towards the U.S. model of corporate governance, which would "be one of the first examples of an agreed-upon theoretical development across national boundaries in law"). 
analytical framework that can be applied to discern how legal scholarship evolves over time. 